\title{
Quantitative clay mineralogy as a tool for lithostratigraphy of Neogene Formations in Belgium: a reconnaissance study
}

\author{
RIEKO ADRIAENS ${ }^{1 *} \&$ NoËL VANDENBERGHE ${ }^{2}$
}

\author{
${ }^{1}$ Qmineral Analysis \& Consulting, Heverlee, Belgium; radriaens@qmineral.com. \\ ${ }^{2}$ Dept. Earth and Environmental Sciences, KU Leuven, Belgium; noel.vandenberghe@kuleuven.be. \\ * corresponding author.
}

\begin{abstract}
Although the main stratigraphic frame of the Neogene in North Belgium is well established still several issues remain. This is in particular the case at the boundaries of lithostratigraphic units and where lateral facies have developed. Not only are more biostratigraphic data needed but also the commonly used geophysical well logging needs a better information on the precise influence of the variable mineralogy in the sediments. In particular glauconite, muscovite and clay mineralogy need a detailed analysis. Such an analysis is carried out on the Antwerp Member of the Berchem Formation, the Diest Formation, the Kasterlee Formation and the Mol Formation with particular emphasis on the boundary intervals between these units. Clay minerals, glauconite, feldspars and muscovite are analyzed. Interstratified glauconite/smectite appears to be common in the low abundant dispersed clay fraction of sand rich in glauconite pellets. Marine units generally consist of detrital smectite-rich assemblages while kaolinite becomes more abundant in units under more continental influence. The presence of Fe-rich vermiculite in a clayey top facies of the Diest Formation indicates the influx of soil material containing weathered glauconite. It is common to find that the basal sediments of a new unit contain the mineralogical heritage of the underlying unit. The clay mineral content has helped to differentiate between units, to locate the boundaries between units and to understand the reworking that occurred at the base of new stratigraphic units. The mineralogical information can also be used to interpret the natural radioactivity and resistivity signals in the borehole logs.
\end{abstract}

KEYWORDS: Berchem Formation, Diest Formation, Kasterlee Formation, Mol Formation, glauconite, vermiculite, reworking.

\section{Introduction}

The occurrence of Neogene deposits in Belgium is restricted to the north to northeastern part of the country, more specifically in the Campine and Hageland areas and has a dominantly sandy character. Deposition occurred in a shallow marine environment, as evidenced by the fossil content and the considerable pelletal glauconite content. Simultaneously, the increasing influence of the Rhine graben in the east also resulted in the deposition of more continental white quartz sand deposits (Databank Ondergrond Vlaanderen, 2020). The stratigraphy of these Neogene deposits in North Belgium still has pending issues.

In their respective stratotype areas the established stratigraphic units (Laga et al., 2001) can be successfully differentiated based on grain size, pelletal glauconite content and carbonate content. However, towards stratigraphic boundaries clear sharp lithological boundaries are often lacking and also lithological characteristics seem to vary laterally.

A second issue is that for many sections a chronostratigraphic framework is lacking. After the pioneering work by Gulinck, Laga and De Meuter (Gulinck, 1963; De Meuter \& Laga, 1976) in Neogene biostratigraphy using calcareous fossils in the previous century, a more complete chronostratigraphic framework for the Neogene was only achieved by the work of Louwye and co-workers (e.g. Louwye, 2000; 2005; Louwye \& De Schepper, 2010; Louwye et al., 1999; 2007) who were able to date and laterally correlate several formations and subunits using dinoflagellate biocysts. However still many relevant sections and boreholes are waiting for analysis. As a consequence, sediment provenance systems and entire sedimentological models often are still under debate.

A more detailed knowledge of the Neogene stratigraphy is relevant as the Neogene forms an important aquifer system in the Campine and therefore is important in the framework of the research for low-level radioactive waste storage in Belgium. It is also in this context that a drilling program in the region of the villages Mol - Dessel - Kasterlee was set up by ONDRAF/ NIRAS a few decades ago, which resulted in several closely spaced boreholes with optimally preserved cores. Even the stratigraphical interpretation of these well-documented boreholes appeared surprisingly difficult. An interpretation was worked out mainly based on core description, gamma-ray values and grainsize content (Vandenberghe et al., 2020, this volume). Additional use was made of cone penetration testing (Schiltz, 2020, this volume) and also the mineralogy presented in this work was used in support of the interpretations. For many potentially relevant boreholes such systematic data collection does not exist yet.

Gamma-ray and resistivity logging are becoming increasingly important in the stratigraphic interpretation. However, a proper interpretation of the signals depends on a good understanding of the mineralogy of the sediments. The potassium, uranium and thorium contents determining the gamma-ray values depend on the mineral content in an often complex manner and also the particular influence of different minerals on the electrical conductivity in a sediment is often underestimated, for instance the influence of pelletal glauconite. Therefore more systematic qualitative and quantitative mineralogical analysis of sediment sequences is needed.

In this paper the potential of using clay mineralogy for characterizing Neogene stratigraphic units such as the Berchem, Diest, Kasterlee and Mol Formations and in particular their boundaries is explored in several core and outcrop sections.

These data have also been used in support of stratigraphic interpretations and discussions in this Neogene volume (Vandenberghe et al., 2020, this volume; Houthuys et al., 2020, this volume).

\section{Neogene stratigraphy in North Belgium}

A complete overview of the different Neogene Formations and Members in North Belgium can be consulted in the editorial article of this volume (Vandenberghe \& Louwye, 2020, this volume). Below, the most crucial features of the investigated Formations are discussed (see Fig. 1). The oldest Neogene sediments belong to the Berchem and Bolderberg Formations (Louwye et al., 2020, this volume). Of the Berchem Formation only the Antwerp Member is studied; it is the most widely occurring Member of early Miocene age in the west and central Campine. The Antwerp Member is a fine to medium fine often clayey sand known for its very high concentration of pelletal glauconite.

The Tortonian Diest Formation consists of the calcareous Deurne and finer-grained Dessel Members but the large majority of the Diest Formation is grouped under the Diest sand member; this last newly proposed unit consists of all sand of the Diest Formation without its formally Deurne and Dessel Members. The Diest sand member is in this work further subdivided in two units. The first unit is the coarser main body consisting of medium- to coarse-sized glauconitic sand with a generally low clay content and sometimes intensively bioturbated (termed "Diest D1" facies in Adriaens, 2015). This coarse main body occurs both in the Campine as in the Hageland area (Fig. 1). In the Campine area, the coarse Diest sand is covered by the clayey top of the Diest Formation. This clayey top ("Diest D4" facies in Adriaens, 2015) is the second unit; it reaches a thickness of $10-15 \mathrm{~m}$, is also glauconite-rich and has a characteristic higher clay content compared to the clay-poor coarser main body of the Diest sand member.

A depositional model for the Diest Formation was presented by Vandenberghe et al. (2014) who concluded based on pelletal glauconite $\mathrm{K}-\mathrm{Ar}$ ages that a considerable part of the Diest 
Figure 1. Geological map of north to northeastern part of Belgium with indication of the Neogene formations and the borehole and outcrop locations which are referred to in this study (modified after Databank Ondergrond Vlaanderen, 2020).

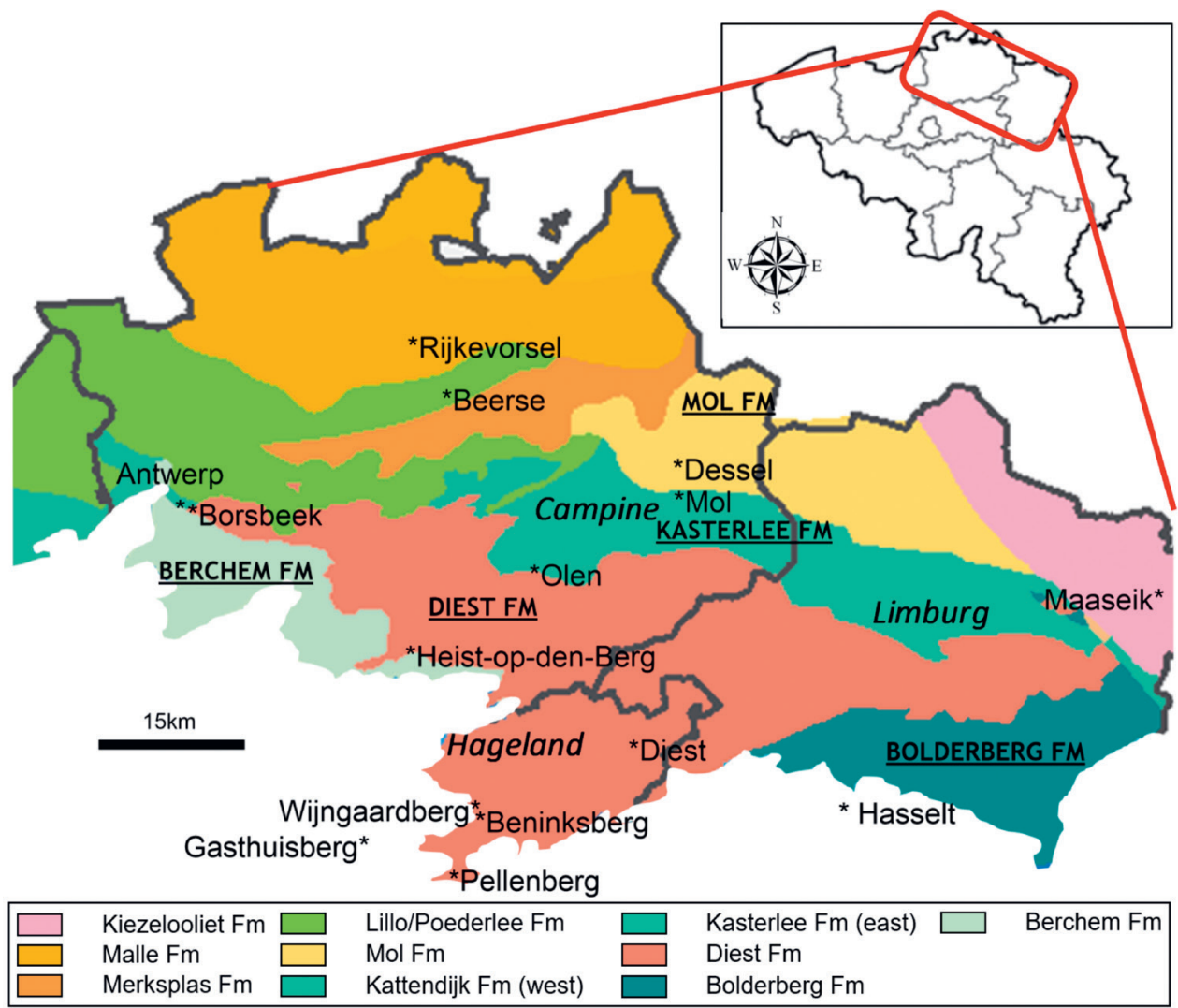

Formation sediment has been reworked from older Miocene deposits (see also Houthuys et al., 2020, this volume).

The overlying late Miocene Kasterlee Formation was also deposited in shallow marine conditions, but is a clearly finer-sized and better-sorted sand with low pelletal glauconite contents. The thickness of the Kasterlee Formation is restricted to maximum 10 $\mathrm{m}$. Wouters \& Schiltz (2011) have made the differentiation between a sandy upper part and a much more clayey lower part in the area east of the village Kasterlee, which is very pronounced in logging traces. Vandenberghe et al. (2020, this volume) have named this sandy upper Kasterlee unit the 'lower Mol' or 'Kasterleesensu-Gulinck' unit and the lower part 'clayey Kasterlee'. While the latter unit undoubtedly is ranged in the classical Kasterlee Formation, for the time being it is still undecided whether the former unit should be associated with the classical overlying Mol Formation or with the Kasterlee Formation (see discussion in Vandenberghe et al., 2020, this volume). The youngest studied unit is the Pliocene Mol Formation that consists of continental to estuarine white quartz sand with no or only very little pelletal glauconite amounts, although a distinct green coloration of the base of the Mol Formation is often reported, leading to the informal use of the poorly defined and therefore to be abandoned term 'Mol Inférieur' in borehole descriptions.

Based on these general definitions of the different stratigraphic units, a basic stratigraphic succession commonly can be identified in the central Campine; however facies evolve laterally and also the lithology at the boundaries between the units can become complex as demonstrated in several papers in this volume.

\section{Glauconite minerals in the Neogene deposits}

The characteristic property of the Neogene deposits in Belgium is the presence of glauconitic minerals. Because of its relatively high potassium content and electrical conductivity, glauconitic minerals strongly influence continuous gamma-ray and resistivity logging readings. It is therefore important to fully understand the characteristics of glauconitic minerals.

Sand-sized glauconite pellets occur abundantly in the Berchem and Diest Formations. The pelletal glauconite content of the Berchem Formation is on average $47 \%$ and ranges from $28 \%$ to contents up to $85 \%$ in certain horizons. The pelletal glauconite content of the Dessel Member of the Diest Formation ranges from $16 \%$ to $35 \%$ with an average of $26 \%$ whereas the range in the Diest sand member is between $16 \%$ and $67 \%$, with an average of $38 \%$ (Adriaens, 2015). The Kasterlee Formation contains less pelletal glauconite, typically $3-6 \%$. Pelletal glauconite in the Pliocene Mol Formation is usually only present as a trace $(<0.01 \%)$ or is absent.

Based on K-Ar dating, grain-size distributions and general sedimentological characteristics, Vandenberghe et al. (2014) and Adriaens (2015) concluded that the large majority of the pelletal glauconite in the Neogene underwent significant transport or was reworked from older deposits. The pelletal glauconite in the Antwerp Member of the Berchem Formation is probably the only occurrence where the pellets were at least partially authigenically formed.

Adriaens et al. (2014) demonstrated that the glauconite minerals do not only occur in sand-sized pellets but also in clay-sized fractions ("clay-sized glauconite") (see also Table 1). This clay-sized glauconite originates from the abrasion and disintegration of the pelletal glauconite upon transport or even during compaction. Although clay-sized glauconite occurs abundant as diffusely-distributed clay particles in glauconitic sand sediment ("dispersed clay"), it appears to be systematically absent in clay lenses, which confirms that pellet degradation is a local process limited to the depositional environment of the coarser sand. The occurrence of clay-sized glauconite therefore indicates energetic conditions in the depositional environment although the relative quantities of clay-sized glauconite in sediments evidently also depend on the clay quantity in the sample. Also reworking can increase the content of clay-sized glauconite in sediments.

The mineralogy of the pelletal and clay-sized forms are nearly identical in the same sample. The exact mineralogical composition is not the pure end-member mineral glauconite ("glauconite mica" with structural formula $(\mathrm{K}, \mathrm{Na})\left(\mathrm{Fe}^{3+}, \mathrm{Fe}^{2+}, \mathrm{Al}\right.$, $\left.\mathrm{Mg})_{2}(\mathrm{Si}, \mathrm{Al})_{4} \mathrm{O}_{10}(\mathrm{OH})_{2}\right)$ but an interstratified clay mineral phase with alternating glauconite and smectite layers (Van Ranst \& De Coninck, 1983). Typically, the glauconite/smectite interstratified clay mineral found in the Neogene in Belgium is composed of $70 \%$ to $90 \%$ glauconite (end-member "glauconite mica") layers and $10 \%$ to $30 \%$ smectite layers (Adriaens et al., 2014). The smectite species of the interstratified glauconite/smectite mineral is not easily identified. Most logically, it is a dioctahedral Ferich species; thus either nontronite, Fe-rich montmorillonite or Fe-rich beidellite (Meunier \& El Albani, 2005). The difference is based on the dominant location and magnitude of the layer charge which can be assessed from the structural formula or 


\begin{tabular}{|c|c|c|c|c|}
\hline Mineral species & Theoretical composition & $d_{(060)}(\AA)$ & $\begin{array}{l}\text { Primary } \\
\text { Clay fraction } \\
<2 \mu \mathrm{m}\end{array}$ & $\begin{array}{l}\text { urrence } \\
\text { Silt \& sand } \\
\qquad 2 \mu \mathrm{m}\end{array}$ \\
\hline Silicates & & & & \\
\hline Quartz & $\mathrm{SiO}_{2}$ & & & $\mathrm{x}$ \\
\hline Alkali feldspar & $(\mathrm{K}, \mathrm{Na}) \mathrm{AlSi}_{3} \mathrm{O}_{8}$ & & & $\mathrm{x}$ \\
\hline Plagioclase & $(\mathrm{Na}, \mathrm{Ca}) \mathrm{AlSi}_{3} \mathrm{O}_{8}$ & & & $\mathrm{x}$ \\
\hline Carbonates & & & & \\
\hline Calcite & $\mathrm{CaCO}_{3}$ & & $\mathrm{x}$ & $\mathrm{x}$ \\
\hline Siderite & $\mathrm{FeCO}_{3}$ & & & $\mathrm{x}$ \\
\hline 2:1 Layer silicates (dioctahedral) & & & & \\
\hline Muscovite & $\mathrm{KAl}_{2}\left(\mathrm{Si}_{3} \mathrm{Al}\right) \mathrm{O}_{10}(\mathrm{OH}, \mathrm{F})_{2}$ & 1.50 & & $\mathrm{x}$ \\
\hline Illite & $\mathrm{K}(\mathrm{Al}, \mathrm{Mg}, \mathrm{Fe})_{2}(\mathrm{Si}, \mathrm{Al})_{4} \mathrm{O}_{10}\left[(\mathrm{OH})_{2},\left(\mathrm{H}_{2} \mathrm{O}\right)\right]$ & 1.50 & $\mathrm{x}$ & \\
\hline Smectite & $(\mathrm{Na}, \mathrm{Ca})_{0,3}(\mathrm{Al}, \mathrm{Mg})_{2} \mathrm{Si}_{4} \mathrm{O}_{10}(\mathrm{OH})_{2} \bullet n\left(\mathrm{H}_{2} \mathrm{O}\right)$ & 1.50 & $\mathrm{x}$ & \\
\hline $\begin{array}{l}\text { Interstratified illite/smectite } \\
\text { Interstratified } \\
\quad \text { glauconite/smectite } \\
\quad \text { (Berchem Fm average) }\end{array}$ & $\begin{array}{c}(\mathrm{Na}, \mathrm{Ca}, \mathrm{K})(\mathrm{Al}, \mathrm{Mg}, \mathrm{Fe})_{2}(\mathrm{Si}, \mathrm{Al})_{4} \mathrm{O}_{10}\left[(\mathrm{OH})_{2},\left(\mathrm{H}_{2} \mathrm{O}\right)\right] \\
\left(\mathrm{Na}_{0.09}, \mathrm{Ca}_{0.03}, \mathrm{~K}_{0.62}\right)\left(\mathrm{Fe}^{3+}{ }_{1.11}, \mathrm{Fe}^{2+}{ }_{0.17}, \mathrm{Al}_{0.43}, \mathrm{Mg}_{0.36}\right)_{2} \\
\quad\left(\mathrm{Si}_{3.53}, \mathrm{Al}_{0.47}\right)_{4} \mathrm{O}_{10}\left[(\mathrm{OH})_{2},\left(\mathrm{H}_{2} \mathrm{O}\right)\right]\end{array}$ & 1.50 & $\mathrm{x}$ & \\
\hline $\begin{array}{l}\text { Interstratified } \\
\text { glauconite/smectite (Diest } \\
\text { Fm average) } \\
\text { Interstratified } \\
\text { glauconite/smectite } \\
\quad \text { (Kasterlee Fm average) }\end{array}$ & $\begin{array}{l}\left(\mathrm{Na}_{0.03}, \mathrm{Ca}_{0.02}, \mathrm{~K}_{0.64}\right)\left(\mathrm{Fe}^{3+}{ }_{1.10}, \mathrm{Fe}^{2+}{ }_{0.14}, \mathrm{Al}_{0.48}, \mathrm{Mg}_{0.36}\right)_{2} \\
\quad\left(\mathrm{Si}_{3.57}, \mathrm{Al}_{0.37}\right)_{4} \mathrm{O}_{10}\left[(\mathrm{OH})_{2},\left(\mathrm{H}_{2} \mathrm{O}\right)\right] \\
\left(\mathrm{Na}_{0.04}, \mathrm{Ca}_{0.02}, \mathrm{~K}_{0.57}\right)\left(\mathrm{Fe}^{3+}{ }_{1.06}, \mathrm{Fe}^{2+}{ }_{0.09}, \mathrm{Al}_{0.6}, \mathrm{Mg}_{0.31}\right)_{2} \\
\quad\left(\mathrm{Si}_{3.42}, \mathrm{Al}_{0.44}\right)_{4} \mathrm{O}_{10}\left[(\mathrm{OH})_{2},\left(\mathrm{H}_{2} \mathrm{O}\right)\right]\end{array}$ & $1.513-1.519$ & $\begin{array}{l}\text { Clay-size } \\
\text { Pelletal }\end{array}$ & $\begin{array}{l}\text { auconite } \\
\text { uconite }\end{array}$ \\
\hline 2:1 Layer silicates (trioctahedral) & & & & \\
\hline Vermiculite (Fe-rich) & $(\mathrm{Na}, \mathrm{Ca})(\mathrm{Fe}, \mathrm{Mg}, \mathrm{Al})_{3}(\mathrm{Al}, \mathrm{Si})_{4} \mathrm{O}_{10}(\mathrm{OH})_{2} \bullet 4(\mathrm{H} 2 \mathrm{O})$ & $1.53-1.54$ & $\mathrm{x}$ & \\
\hline 1:1 Layer silicates & & & & \\
\hline Kaolinite & $\mathrm{Al}_{2} \mathrm{Si}_{2} \mathrm{O}_{5}(\mathrm{OH})_{4}$ & 1.49 & $\mathrm{x}$ & \\
\hline 2:1:1 Layer silicates & & & & \\
\hline Chlorite & $(\mathrm{Fe}, \mathrm{Mg})_{5} \mathrm{Al}\left(\mathrm{Si}_{3} \mathrm{Al}\right) \mathrm{O}_{10}(\mathrm{OH})_{8}$ & $1.53-1.55$ & $\mathrm{x}$ & $\mathrm{x}$ \\
\hline
\end{tabular}

Table 1. Overview of the most important mineral and clay mineral species mentioned in this work. The theoretical structural formula is given together with their primary occurrence in the sediment: in the clay fraction $<2 \mu \mathrm{m}$ or in silt and sand fractions $>2 \mu \mathrm{m}$. The interstratified glauconite/smectite mineral occurs both in the clay fraction ("clay-sized glauconite") and as silt- and sand-sized glauconite pellets. The column $d_{(06)}$ lists the normal diffraction position of the 060-parameter of the different layer silicates and provides an indication of the octahedral cation occupancy. For the interstratified glauconite/smectite mineral, the $d_{(06)}$ is a direct measure for the octahedral Fe content. The structural formula of interstratified glauconite/smectite is given as the average of actual structural formula of chemically analyzed purified pelletal glauconites of the Berchem Formation, the Diest Formation and the Kasterlee Formation (Adriaens et al., 2014).

indirectly by ambiguous tests such as the Green-Kelly test (Moore \& Reynolds, 1997). Based on the structural formula of several Neogene pelletal glauconites (Adriaens et al., 2014; see Table 1) it is deduced that in general tetrahedral charge is slightly more dominant (circa 55-60\%), suggesting nontronite or Fe-rich beidellite being the dominant smectite species. Nevertheless, in two Berchem and Diest Formation samples, the layer charge is mainly octahedral (55\%), suggesting the smectite species is Femontmorillonite. Although Van Ranst \& De Coninck (1983) have suggested that the smectite species is nontronite, we will not further specify the smectite species, as we have no certainty on the exact layer type. Aside from the elevated potassium content $(4.5 \%$ to $7 \%)$, these glauconitic minerals also have high iron contents, ranging from $15 \%$ to $22 \%$ total $\mathrm{Fe}_{2} \mathrm{O}_{3}$ (Adriaens et al., 2014). The iron content is a useful proxy for the depositional history of glauconitic minerals. Upon evolution and maturity of glauconite, the iron content increases whereas processes such as weathering, reworking or changes in redox conditions can selectively leach iron from the mineral structure. The iron content of glauconitic minerals is in X-ray diffraction patterns reflected in the position of the (060) diffraction band, which reflects the b-cell parameter of the mineral structure and the octahedral cation occupancy. The position of the (060) diffraction band therefore is an estimate of the iron content of the pelletal glauconite.

It is clear that a systematic characterization of the occurrence, quantity and type of glauconitic minerals is crucial in this lithostratigraphic debate. The absence of clay-sized glauconite in clay lenses also learns that it is important to make separate analysis of the clay fraction in the sandy sediments and the clay that occurs in the intercalated lenses.

\section{Materials and methods}

Samples were collected from various cored boreholes in the Campine subsurface and outcrops in the southern Campine and Hageland area (see Fig. 1 for locations). Samples from the Berchem-Diest transition were collected from the Rijkevorsel borehole (DOV kb8d16e-B37_BGD 016E153) and the ONDessel-5 borehole (DOV ON-Dessel-5 BGD 031W0370). Three samples were collected at the base of the Deurne Member in a temporary outcrop in Borsbeek (see Goolaerts et al, 2020, this volume), near the Deurne airport. The Diest Formation in the Campine subsurface was sampled in the Pidpa Put- 8 borehole (DOV B/1-96196 BGD 031E0435, a non-cored watercirculation drilling) and in various outcrops in the Hageland such as Gasthuisberg (DOV TO-20150101A), Beninksberg (DOV TO-20150101B), Wijngaardberg (DOV TO-20150101C) and Pellenberg "Steenrots" (DOV kb32d90w-B958). Samples from the Diest-Kasterlee-Mol transition were collected in the Mol-Dessel type area from the ONDRAF/NIRAS boreholes ON-Dessel-2 (DOV kb17d31w-B299_BGD 031W0338) and ON-Dessel-3 (DOV ON-Dessel-3 BGD 031W0354). In these boreholes, in total 37 sand and clay-lens samples for ON-Dessel-2 
and 32 samples for ON-Dessel-3 were collected. The DiestKasterlee boundary was furthermore sampled at the outcrops of Heist-op-den-Berg (DOV TO-19950101A) and Olen sluice (DOV GRAN-BGD045w0253 BGD 045W0253). More details of all boreholes and outcrops can be consulted at https://www. dov.vlaanderen.be/data/opdracht/2020-022012.

Mineralogical analyses were performed after $24 \mathrm{~h}$ gentle stirring in water and wet sieving at $32 \mu \mathrm{m}$. The $<32 \mu \mathrm{m}$ fraction was separated from the sediment after optimal dispersion of the sediment in water achieved by a sequential procedure of stirring and wet sieving until the supernatant water of the $>32 \mu \mathrm{m}$ fraction is clear and no suspended sediment was visually observed in the fraction $>32 \mu \mathrm{m}$. It was shown in Adriaens et al. (2014) that this procedure does not cause significant pelletal glauconite disintegration in contrast to the further chemical preparation for clay mineralogical analysis. It is therefore crucial that pelletal glauconite is removed from the sediment as much as possible prior the clay mineralogical analysis. A sieve mesh size of 32 $\mu \mathrm{m}$ was chosen as the best compromise between on one hand extracting the optimal amount of pelletal glauconite $(>32 \mu \mathrm{m})$ and a practical sieve mesh size for wet sieving the samples.

The clay mineralogy of the $<2 \mu \mathrm{m}$ of the samples was determined on a representative portion of the $<32 \mu \mathrm{m}$ fraction after removal of cementing agents. Carbonates cements were removed by a $\mathrm{pH} 5$ buffer solution of $\mathrm{Na}$-acetate and acetic acid, organic matter was oxidized by a $7 \% \mathrm{H}_{2} \mathrm{O}_{2}$ solution whereas free Fe oxides-hydroxides were removed by the Citrate-BicarbonateDithionite method (modified after Jackson, 1975). These steps are combined by ultrasonic treatment to further loosen aggregates. Clay fractions $<2 \mu \mathrm{m}$ were isolated using timed centrifugation and subsequently Ca-saturated before making oriented clay slides on glass by sedimenting clay slurries. X-ray diffraction measurements were recorded on a Phillips PW1830 diffractometer with Bragg-Brentano setup equipped with $\mathrm{Cu}$ $\mathrm{K} \alpha$ radiation, a graphite monochromator and gas proportional detector. Measurements were recorded at $45 \mathrm{kV}$ and $30 \mathrm{~mA}$ from $2-47^{\circ} 2 \Theta$ with $0.02^{\circ} 2 \Theta$ step size and $2 \mathrm{~s}$ counting time in normal air-dry state and solvated with ethylene glycol. When necessary for identification, additional saturations with $\mathrm{K}+$ heating at 300 ${ }^{\circ} \mathrm{C}$, with $\mathrm{Mg}$ and glycerol intercalation and Li combined with 300 ${ }^{\circ} \mathrm{C}$ heating and glycerol solvation by brush were applied (after Moore \& Reynolds, 1997). Based on these XRD measurements, clay minerals such as kaolinite, illite, smectite, vermiculite, chlorite and interstratified clay minerals (glauconite/smectite, illite/smectite) can be readily identified. Quantification of the clay mineral fraction was performed using diffraction pattern modeling by the software Sybilla (CChevron ETC).

The bulk mineralogical composition was also determined on the $<32 \mu \mathrm{m}$ fraction as many of the collected samples are sanddominated by quartz and many minerals of interest might not be detected by X-ray diffraction. The mineralogical composition of the $<32 \mu \mathrm{m}$ fraction was determined by quantitative X-ray powder diffraction on random orientation powders prepared by side loading. X-ray diffraction measurements were recorded on a Phillips PW1830 diffractometer with Bragg-Brentano setup equipped with $\mathrm{Cu}-\mathrm{K} \alpha$ radiation, a graphite monochromator and gas proportional detector. Measurements were recorded at 45 $\mathrm{kV}$ and $30 \mathrm{~mA}$ from $5-65^{\circ} 2 \Theta$ with $0.02{ }^{\circ} 2 \Theta$ step size and $2 \mathrm{~s}$ counting time. The powders were prepared after addition of $10 \%$ internal standard $(\mathrm{ZnO})$ and $\mathrm{McCrone}$ milling in ethanol for 10 min. Interpretation was performed using a pattern summation method incorporated in the software QUANTA (CChevron ETC).
Figure 2. Overview of the clay mineralogy, pelletal glauconite content, mineralogical parameters and grain-size classes of the different analyzed sand samples of the Rijkevorsel borehole. The boundary between the Berchem $\mathrm{Fm}$ and the Dessel Member (Diest Fm) is based on Gulinck \& Laga (1975).

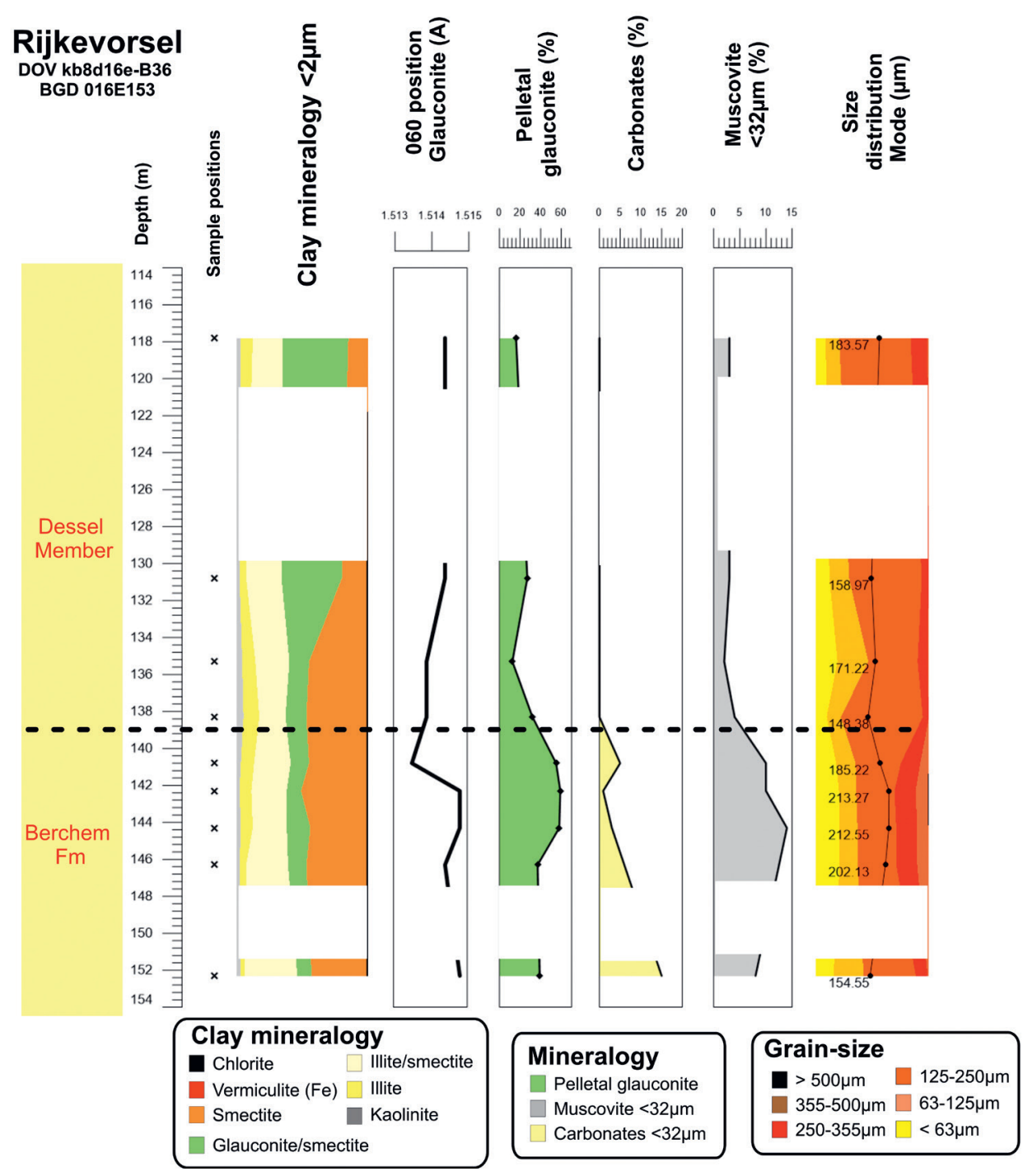


Pelletal glauconite was magnetically separated from the $>32 \mu \mathrm{m}$ fraction using a Frantz isodynamic magnetic separator to determine the pelletal glauconite content by weight. The isolated glauconite fraction was then also investigated using X-ray diffraction in order to characterize the (060) diffraction band.

Grain-size analyses were performed as a supporting analysis with laser diffraction using a Malvern Mastersizer-S. The results are presented in six size classes: $<63 \mu \mathrm{m}, 63-125 \mu \mathrm{m}, 125-$ $250 \mu \mathrm{m}, 250-355 \mu \mathrm{m}, 355-500 \mu \mathrm{m}$ and $>500 \mu \mathrm{m}$.

An overview of the characteristics of all minerals and clay minerals that are discussed in this work can be consulted in Table 1 .

\section{Results}

\subsection{The Berchem-Diest boundary in the Rijkevorsel borehole}

The Berchem-Diest boundary in the Rijkevorsel borehole (DOV kb8d16e-B37 BGD 016E153) (Fig. 2) was identified by Gulinck \& Laga (1975). They identified the Antwerp Member of the Berchem Formation in the $138.10 \mathrm{~m}-154 \mathrm{~m}$ interval overlain by the Dessel Member between $111 \mathrm{~m}$ and $138.10 \mathrm{~m}$; the Dessel Member between $111 \mathrm{~m}$ and $135.9 \mathrm{~m}$ contains no carbonates.

The clay mineralogy of the $<2 \mu \mathrm{m}$ fraction of the Antwerp Member sand samples typically is smectite-rich (typically 40-50\%) whereas interstratified illite/smectite, illite and interstratified glauconite/smectite are less abundant. Kaolinite in the Antwerp Member is rare; it only occurs in quantities lower than $6-7 \%$. This clay mineralogical assemblage with mainly smectite and interstratified illite/smectite and little kaolinite and illite is dominantly detrital and marine-derived as smectitic clay minerals are omnipresent in all marine deposits of Miocene, Oligocene and even Eocene age in the Campine basin.

Above the $138.10 \mathrm{~m}$ boundary, the Dessel Member of the Diest Formation occurs. The clay mineralogical composition of the $<2 \mu \mathrm{m}$ fraction of the basal samples is still smectite-rich but the smectite content decreases while interstratified glauconite/smectite is more prominent further up in the borehole. This increase of claysized glauconite in the Dessel Member indicates either an increased impact energy between pelletal glauconite grains due to a more energetic sedimentary environment or, more likely, the reworking of glauconitic material from the Antwerp Member.

Glauconite pellets are abundant in the Antwerp Member, ranging from $32 \%$ to $55 \%$, whereas the samples in the Dessel Member above the $138.10 \mathrm{~m}$ boundary clearly contain lower pelletal glauconite contents, ranging from $15 \%$ to $27 \%$. The position of the (060) diffraction band of the glauconitic minerals is slightly lower in the Dessel Member compared to the Antwerp Member which can be interpreted as the loss of structural iron during reworking.

The $138.10 \mathrm{~m}$ boundary is also expressed as a difference in the muscovite content. Muscovite in the Antwerp Member ranges between $7 \%$ and $14 \%$ whereas in the Dessel Member samples muscovite occurs in quantities less than $2 \%$.

The granulometry over the interval indicates a poorlysorted distribution for the Berchem Formation samples with an important fine-sand fraction $(\%<125 \mu \mathrm{m})$. Above the $138.10 \mathrm{~m}$ boundary, fine sand becomes less important and medium-sized sand $(125-250 \mu \mathrm{m})$ becomes the dominant population.

\subsection{The Oligocene Voort Formation, the Berchem Formation and the base of the Diest Formation in the ON-Dessel-5 borehole}

The Berchem-Diest transition in the ON-Dessel-5 borehole (DOV ON-Dessel-5_BGD 031W0370) was interpreted at $139.5 \mathrm{~m}$ based on geophysical well log data combined with lithology descriptions and size distribution data (Labat et al., 2011; Wouters \& Schiltz, 2011). A further subdivision between the calcareous Dessel Member (139.5 m-128 m) and the Diest sand member above was made, although the part above $128 \mathrm{~m}$ is also fine grained and therefore should also be termed Dessel Member (see Houthuys et al., 2020, this volume). This is confirmed by our grain-size data (Fig. 3).

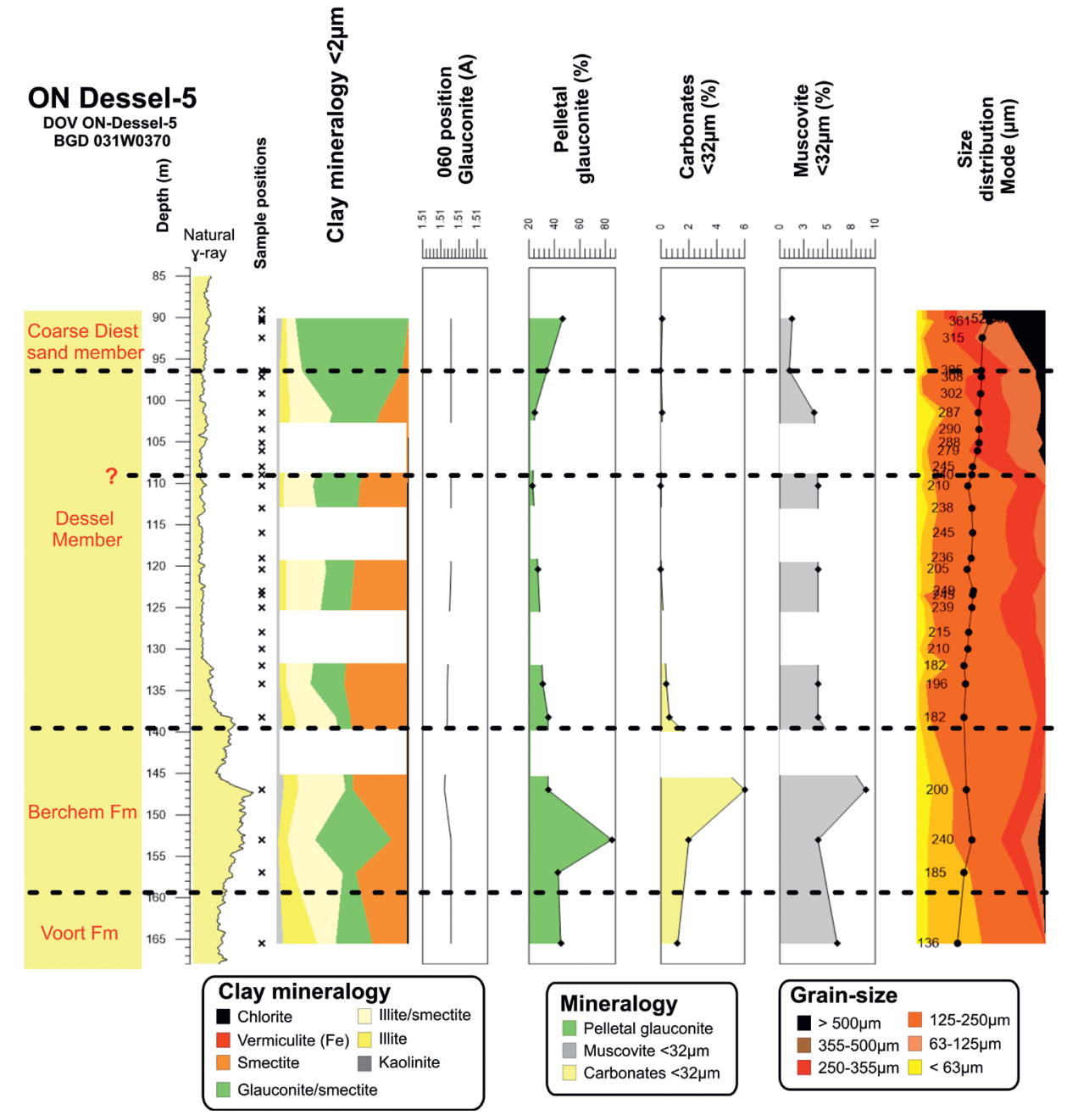

Figure 3. Overview of the clay mineralogy, pelletal glauconite content, mineralogical parameters and grain-size classes of the Dessel-5 borehole. The stratigraphic interpretation of the boundaries between the Voort, Berchem and Diest Formations is based on Labat et al. (2011) and Wouters \& Schiltz (2011). The boundary between the Dessel Member of the Diest Formation and the coarse Diest sand facies is based on the coarsening in grain size and the increase in pelletal glauconite content (see Houthuys et al., 2020, this volume). At approximately $109 \mathrm{~m}$ there is also a grain-size coarsening, this is interpreted as a separate event in the Dessel Member. 
The grain-size analyses show an important fine-sand fraction $(\%<125 \mu \mathrm{m})$ and medium-sized sand fraction $(\%>250 \mu \mathrm{m})$ in the Antwerp Member of the Berchem Formation. In the section above, the amount of grains $<125 \mu \mathrm{m}$ decreases with a dominant population between 125 and $250 \mu \mathrm{m}$. Above $128 \mathrm{~m}$, grain size gradually coarsens. A sharp break in grain size is observed at $110 \mathrm{~m}$, with an increase of the population $>250 \mu \mathrm{m}$. Another break is present around $96 \mathrm{~m}$ where the sediment becomes coarse sand with more than $50 \%$ of the grains $>250 \mu \mathrm{m}$ and the pelletal glauconite also increases to approximately $40 \%$. The break at $96 \mathrm{~m}$ is interpreted as the boundary between the Dessel Member and the coarse Diest sand member ("Diest D1" in Adriaens, 2015).

The clay mineralogy of the Antwerp Member samples is typically rich in smectite although one sample also shows an elevated amount of interstratified glauconite/smectite in the clay fraction. This sample also has a very high pelletal glauconite content of $85 \%$. The clay mineralogy in the Dessel Member is typically similar to that of the Antwerp Member and only changes to a more glauconite/smectite dominated clay mineralogy in the $96.4 \mathrm{~m}$ and $90.14 \mathrm{~m}$ samples. The pelletal glauconite content slightly decreases from $35 \%$ in the Antwerp Member to 23\%$27 \%$ in the Dessel Member above. In the uppermost $96.4 \mathrm{~m}$ and $90.14 \mathrm{~m}$ samples, the pelletal glauconite again increases to $34 \%$ and $46 \%$ respectively. The clay mineralogy also contains less smectite and more clay-sized glauconite. Carbonates are common in the Antwerp Member (2-6\%) and occur only in the lowermost part of the Dessel Member. The muscovite content seems slightly higher in the Antwerp Member (4-9\%) compared to the Dessel Member (around 4\%). In the two uppermost samples (96.4 $\mathrm{m}$ and $90.14 \mathrm{~m}$ ), the muscovite content is lower than $2 \%$.

\subsection{The Deurne Member in the Borsbeek outcrop}

The two lowermost samples from the Borsbeek outcrop ("RU208" and "RU209" in Fig. 4) (see Goolaerts et al., 2020, this volume) were collected in an intensely bioturbated facies less than $1 \mathrm{~m}$ above the base of the Deurne Member, marked by a basal gravel. A third sample ("RU210" in Fig. 4) was collected somewhat higher up in the section, in a less bioturbated part with cross stratification. This last sample was collected in the foresets.

The three Deurne Member samples have a very similar grain-size distribution with distribution modes ranging from $270-280 \mu \mathrm{m}$ and around $12 \%$ of grains $>355 \mu \mathrm{m}$ and pelletal glauconite contents of $46 \%, 39 \%$ and $40 \%$.

The clay composition of the $<2 \mu \mathrm{m}$ fraction of the two bioturbated Deurne Member samples is almost identical with mainly smectite (35-37\%) and interstratified illite/smectite (38\%). Illite occurs between $12-14 \%$ whereas kaolinite is less frequent $(7-8 \%)$ and chlorite only occurs in traces. Interstratified glauconite/smectite occurs only around $4-5 \%$ in bioturbation samples. In the foreset sand sample ("RU210" in Fig. 4), glauconite/smectite ("clay-sized glauconite") is much more abundant $(25 \%)$. The clay mineral composition of these Deurne Member samples is very similar to the composition encountered in the Berchem Formation.

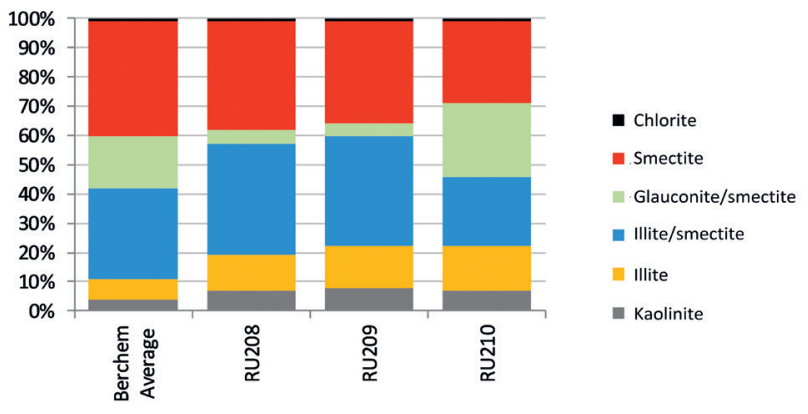

Figure 4. Clay mineralogy of the three investigated Deurne Member samples for the Borsbeek outcrop compared to the average clay mineral composition of the Berchem Formation.

\subsection{The Diest Formation in the Mol 31 E0435 borehole}

In the Mol 31E0435 borehole ("PIDPA Put 8", DOV B/1-96196 BGD 031E0435), a $64 \mathrm{~m}$ section downwards from the top of the Diest Formation was studied in $4 \mathrm{~m}$-spaced samples; each sample is a mixture representative for a $4 \mathrm{~m}$ interval above the indicated sample depth (Fig. 5). The section from $108 \mathrm{~m}$ till approximately $64 \mathrm{~m}$ shows relative uniform characteristics: a coarse sediment with more than $50 \%$ of the grains $>250 \mu \mathrm{m}$ and a low clay content and a typical pelletal glauconite content of $40-47 \%$. The clay mineralogy of the $<2 \mu \mathrm{m}$ fraction of the samples is dominated by interstratified glauconite/smectite whereas expandable clays are not and kaolinite is barely detected. This dominance of claysized glauconite can be understood by the extremely low clay content of the sandy sediment. The absence of clay influx also explains the absence of detrital marine smectite and interstratified illite/smectite clay minerals. The $<32 \mu \mathrm{m}$ fraction of this lower section also systematically contains low amounts of chlorite, muscovite, K-feldspar and plagioclase feldspar. Also secondary formed siderite is detected, of which the typical needle texture was confirmed under the binocular microscope.

In the $60 \mathrm{~m}-44 \mathrm{~m}$ section, the sediment is clearly more fine grained with a slightly increased clay content. The amount of chlorite in the $<32 \mu \mathrm{m}$ fraction slightly increases whereas the pelletal glauconite remains relatively similar. The clay mineralogy is also different with a significant part of expandable clay minerals, i.e. smectite and vermiculite. Based on a further study of the $<0.2 \mu \mathrm{m}$ fraction, it was found that the vermiculite is trioctahedral but also iron-rich (see Adriaens, 2015 for details).

The occurrence of vermiculite in sediments is typical for soil weathering in moderate climatic conditions (Chamley, 1989). However, the top of the Diest Formation in none of the boreholes studied showed a soil-type alteration. Therefore it is assumed that the vermiculite-containing sediment is derived from a more remote source area where a soil could have developed on top of glauconite-rich sand.

Based on these parameters, a boundary between the coarse Diest sand member below and the upper clayey Diest facies is suggested around $60 \mathrm{~m}$. The exact position of this boundary is uncertain because the examined samples are mixed samples over an entire $4 \mathrm{~m}$ interval.

\subsection{The Diest Formation outcropping in the Hageland}

The samples collected at the different Diest Formation outcrops in the Hageland area all consist of medium-sized, often oxidized glauconite-rich sand (Fig. 6). Several brown to red clay layers also occur. The pelletal glauconite contents are on average 38\% and range between $31 \%$ and $58 \%$ in the investigated samples. Except for the samples from the Beninksberg ("RU143" to "RU146" in Fig. 6), grain size of the Diest sediment in the Hageland is composed of at least $40 \%$ of grains larger than $250 \mu \mathrm{m}$. The clay mineralogy of the $<2 \mu \mathrm{m}$ fraction of the sand samples is composed of at least $80 \%$ interstratified glauconite/smectite accompanied by low amounts of illite, interstratified illite/smectite and traces of kaolinite and smectite. As is the case for the Diest Formation in the Campine, the clay mineralogy of the $<2 \mu \mathrm{m}$ fraction of the Diest sand samples in the Hageland is dominated by clay-sized glauconite because of the very low dispersed clay content.

Nevertheless, lenses of brown-colored clay occur in the sand and also thin discontinuous clay laminae occur regularly in the bottom sets of the oblique stratification; the clay mineralogy of the lenses and the laminae is different from the $<2 \mu \mathrm{m}$ fraction mineralogy of the fine clay particles diffusively distributed in the pores of the sand ("dispersed clay"). The clay mineralogy of the clay lenses consists of approximately $30-35 \%$ smectite, $30-40 \%$ interstratified illite/smectite, $10-20 \%$ illite and $10 \%$ kaolinite. Interstratified glauconite/smectite is absent in these concentrated clay occurrences. The difference in clay mineralogy between the sand samples with dispersed clay and concentrated clay is explained by the fact that the smectite and illite/smectitedominated clay mineralogy represents the detrital clay mineral influx during the deposition of the Diest Formation (Tortonian). In the sand lithology, this detrital clay mineral influx is so low that smectite and interstratified illite/smectite occur only in very low quantities compared to clay-sized glauconite causing the 


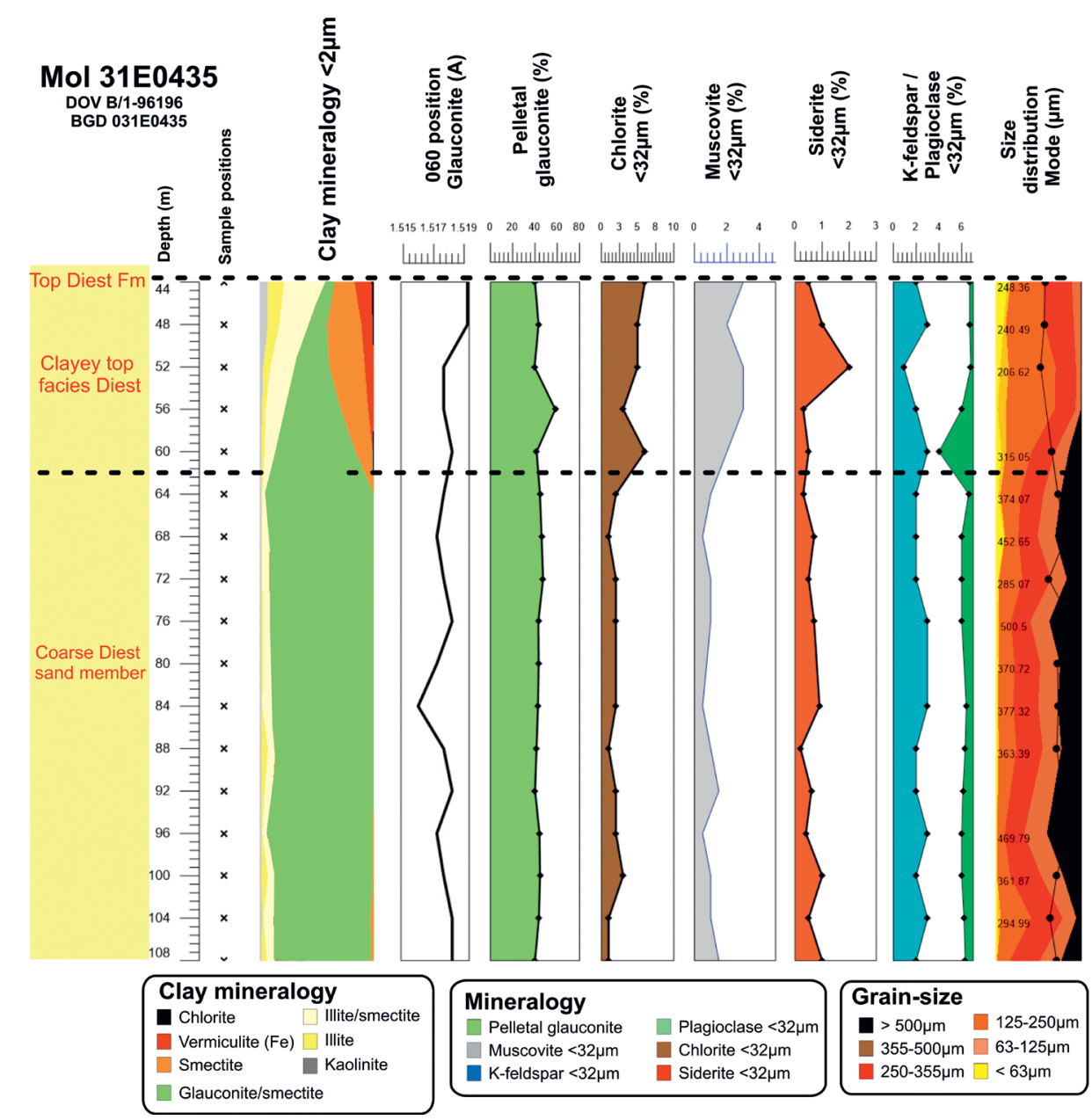

Figure 5. Overview of the clay mineralogy, pelletal glauconite content, mineralogical parameters and grain-size classes of the Mol borehole. The lower part consists of the coarse Diest sand facies characterized by its coarse grain size and interstratified glauconite/smectite ("clay-sized glauconite") dominated clay mineralogy. The upper part is the clayey top facies of the Diest Formation and clearly more finer-sized and the clay mineralogy consists of also smectite and $\mathrm{Fe}$-vermiculite.

process of pelletal glauconite degradation to become the major clay producing mechanism.

\subsection{The Diest-Kasterlee-Mol Formation transition}

\subsubsection{The ON-Dessel-2 borehole}

The stratigraphic boundaries of the ON-Dessel-2 (DOV kb17d31w-B299_BGD 031W0338) are discussed in detail by Vandenberghe et al. (2020, this volume) and are mainly based on characteristic gamma-ray jumps, grain size but also on the presence of basal intervals with reworked sediment. The clay mineralogical variations in the ON-Dessel-2 borehole have allowed to identify these basal reworked sediment intervals leading to an improved understanding of the sedimentary sequence and a more robust definition of the stratigraphic boundary (Figs $7 \& 8$ ).

The sediment analyses performed indicate that the lowermost part between $35 \mathrm{~m}$ and $49 \mathrm{~m}$ is the clayey top facies of the Diest
Formation (facies "Diest D4" in Adriaens, 2015) characterized by a very poorly-sorted size distribution with a significant clay fraction but also a relatively high amount of grains $>355 \mu \mathrm{m}$ and even $>500 \mu \mathrm{m}$. The clay mineralogy of the $<2 \mu \mathrm{m}$ fraction of this section is characterized by high amounts of expandable clay minerals, i.e. dioctahedral smectite and trioctahedral Fe-rich vermiculite and low kaolinite amounts. Clay-sized glauconite, illite and interstratified illite/smectite were also typically present in relatively low quantities. Pelletal glauconite occurs typically between $30 \%$ and $50 \%$ whereas the XRD analysis of the $<32 \mu \mathrm{m}$ fraction also shows the presence of chlorite, (secondary) siderite and plagioclase. A clear break between $34.25 \mathrm{~m}$ and $34.65 \mathrm{~m}$ is observed in the clay mineralogy of clay lenses with significantly less swelling clay minerals (smectite) above this depth. This depth coincides with an important palynological boundary (Louwye et al., 2007) and is interpreted as the Diest-Kasterlee boundary (see Vandenberghe et al., 2020, this volume).

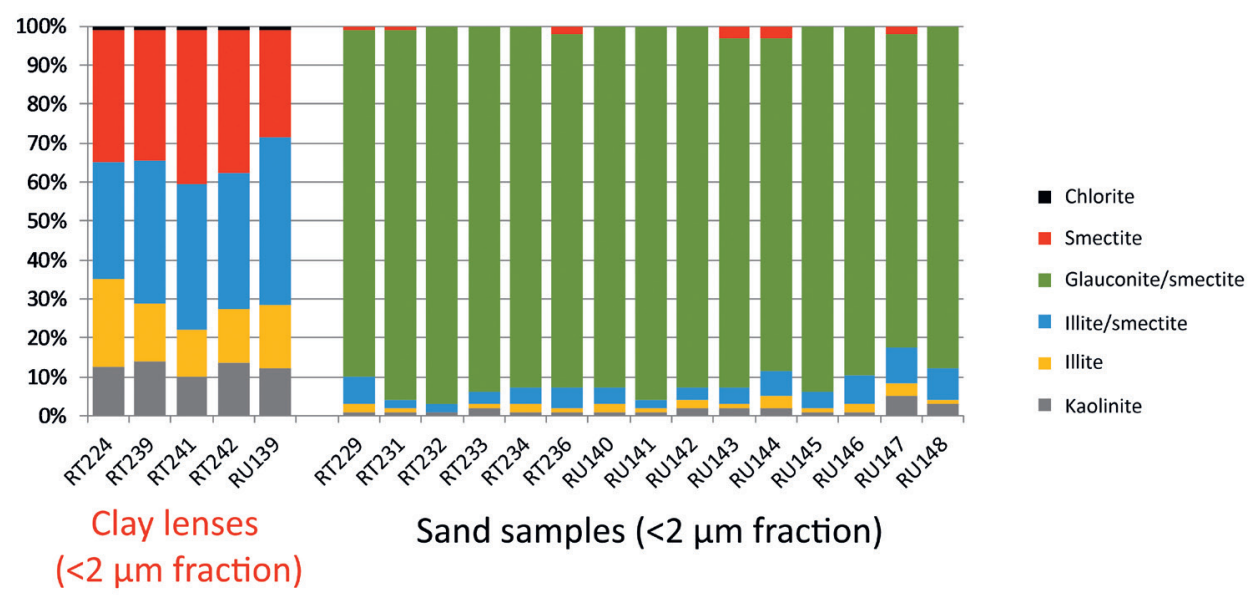

Figure 6. Clay mineralogy of the $<2 \mu \mathrm{m}$ fraction of different samples of the Hageland outcrops subdivided in claylense sediment samples and sand sediment samples containing dispersed clay. The clay-lense sediment samples consist mainly of smectite and interstratified illite/smectite whereas the clay mineralogy of the $<2 \mu \mathrm{m}$ fraction of the sand samples is dominated by interstratified glauconite/smectite ("clay-sized glauconite"). 


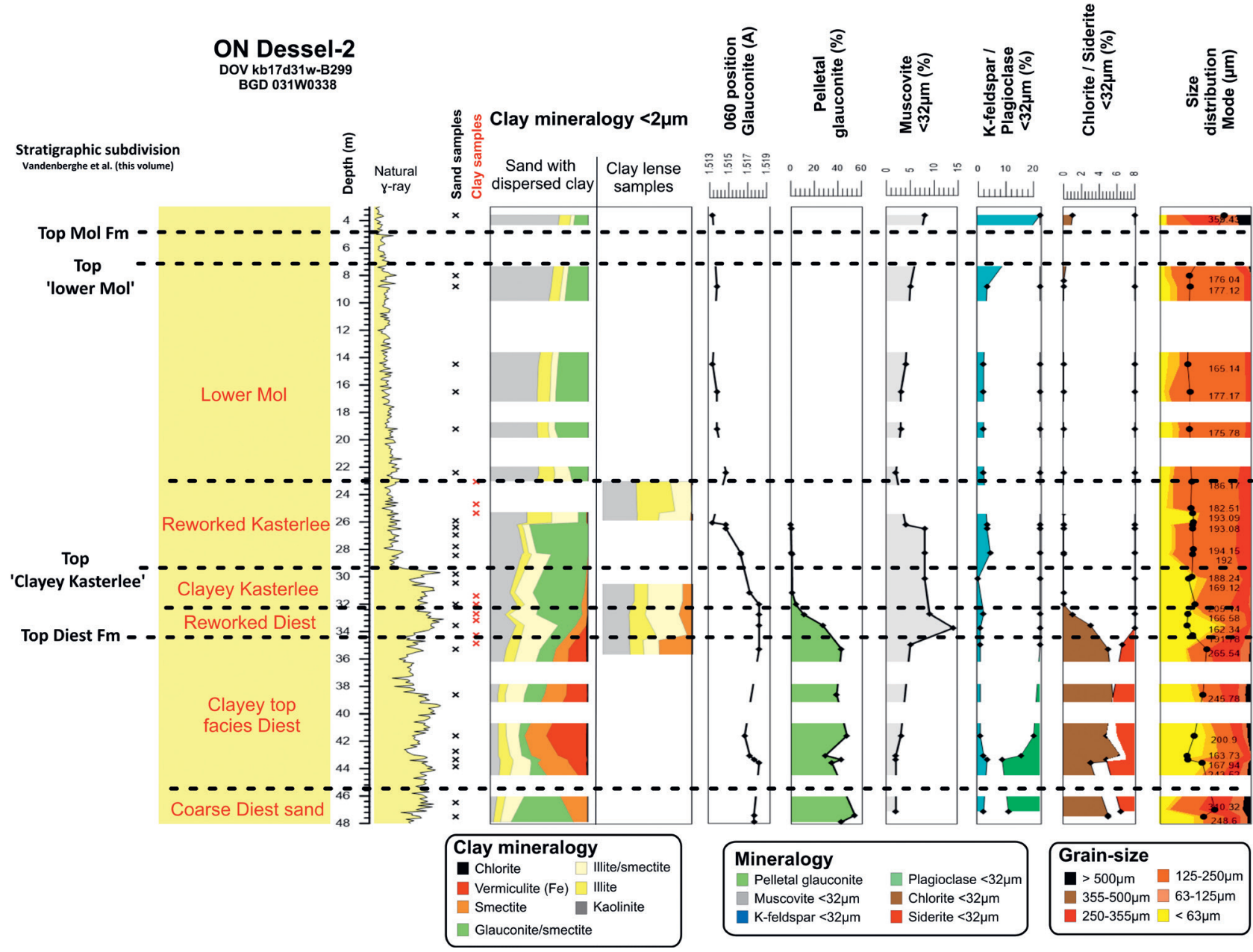

Figure 7. Overview of the clay mineralogy, pelletal glauconite content, mineralogical parameters and grain-size classes of the Dessel-2 borehole. The stratigraphic subdivision is based on Vandenberghe et al. (2020, this volume). Both sand samples (black crosses) as clay lense samples (red crosses) were examined. The clay mineralogy shows an evolution of smectite and Fe-vermiculite in the clayey top facies of the Diest Formation towards more kaolinite and illite in the 'Clayey Kasterlee' unit and even more in the 'Lower Mol' unit.

Above $34.25 \mathrm{~m}$, there is a clear change in sediment properties. The typical mineralogical characteristics of the Diest Formation below $35 \mathrm{~m}$ is replaced by a new association. Upwards from $34.25 \mathrm{~m}$, the contents of the swelling clay minerals, pelletal glauconite, siderite, chlorite and plagioclase clearly decrease whereas the muscovite content increases and the short interval between $34.25 \mathrm{~m}$ and $32.5 \mathrm{~m}$ is interpreted as reworked sediment of the Diest Formation, occurring at the base of the Kasterlee Formation.

In the $32.5 \mathrm{~m}$ to $29.5 \mathrm{~m}$ interval, the sediment is characterized by a finer grain size and medium- to well-sorted grain-size distribution, a clay mineralogy with low amounts of swelling clay minerals and clearly higher kaolinite and clay-sized glauconite contents. Pelletal glauconite contents are below $6 \%$ and muscovite contents have increased to $10 \%$, evidently influencing the GR reading at that level. Vermiculite is also absent above $32.5 \mathrm{~m}$. This sediment is the 'clayey Kasterlee' facies. The top of this interval is marked at a depth of $29.5 \mathrm{~m}$ with a characteristic decrease in the gamma-ray signal. This is interpreted as the boundary between the 'lower Mol' unit and the underlying 'clayey Kasterlee' unit (see Vandenberghe et al., 2020, this volume).

In the $29.5 \mathrm{~m}$ to $23 \mathrm{~m}$ interval, the grain size is more sandy and the clay mineralogy becomes more kaolinite-rich, although clay-sized glauconite remains the most important clay species. Pelletal glauconite, muscovite and feldspar contents remain similar compared to below $29.5 \mathrm{~m}$. At $26 \mathrm{~m}$, the sediment analyses reveal an important event as the amount of claysized glauconite and muscovite sharply decreases whereas the amount of kaolinite progressively increases (Fig. 8). Also the Fe content of the clay-sized glauconite, which already decreased upwards from the $33 \mathrm{~m}$ boundary, is characterized by a sharp decrease above $26 \mathrm{~m}$. Above $26 \mathrm{~m}$, kaolinite also increases whereas muscovite decreases. Pelletal glauconite is virtually absent although clay-sized glauconite, probably reworked, is still present. Dinoflagellate biocysts also disappear above $26 \mathrm{~m}$ (Louwye et al., 2007) which confirms that the $26 \mathrm{~m}$ level is an important event in the evolution of the basin. The $29.5 \mathrm{~m}-23 \mathrm{~m}$ interval is interpreted as a reworked sand interval at the base of the 'lower Mol' unit and within it a particular erosive-reworking phase at $26 \mathrm{~m}$.

The stratigraphic evolution in this borehole is characterized by the gradual increase in kaolinite and decrease of smectite clay minerals and also the Fe content in glauconitic minerals decreases progressively. This evolution is caused by the changes in sedimentary environment from a shallow marine coarse Diest sand member with little or no continental influence over a finegrained Diest clayey top facies with detrital soil particle influx (vermiculite), to a progressively higher continental influx in the Kasterlee Formation and even dominant continental conditions in the Mol Formation (Louwye et al., 2007). The contribution from the continent is expected to source from the Rhine graben area of which Hermanns (1992) documented that these deposits are rich in kaolinite and illitic clay minerals. The decrease in glauconitic $\mathrm{Fe}$ is also explained by the increasing oxidative conditions. Therefore the clay mineralogy reflects the evolution from shallow marine, detrital smectite-rich clay assemblages to progressively more oxidative conditions and continental-derived kaolinite and illitic clay mineral compositions.

The mineralogical and clay mineralogical data in the ONDessel-2 borehole have allowed to identify basal reworking sections at the base of the Kasterlee and Mol Formations. 


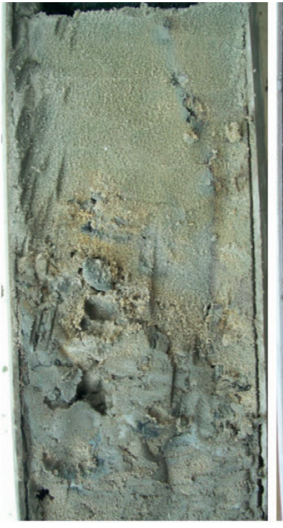

ON-Dessel-2

$25.00-25.25 \mathrm{~m}$

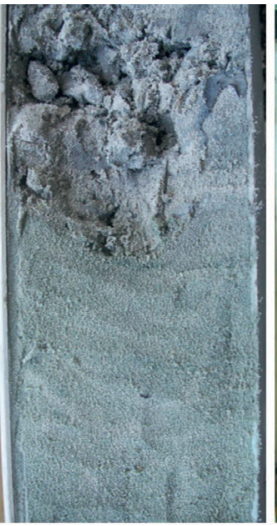

ON-Dessel-2

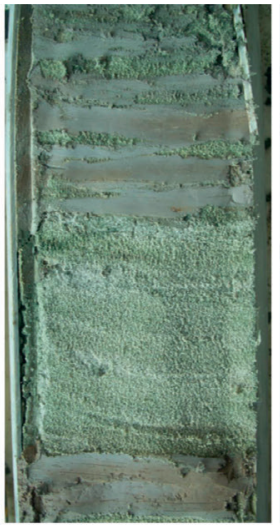

ON-Dessel-2

$31.15-31.40 \mathrm{~m}$

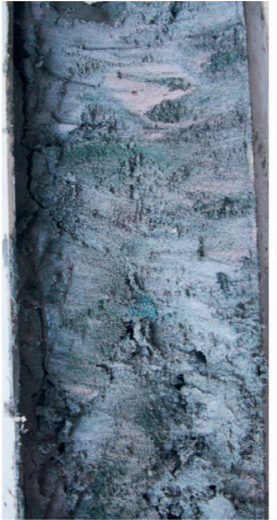

ON-Dessel-2

ON-Dessel-2

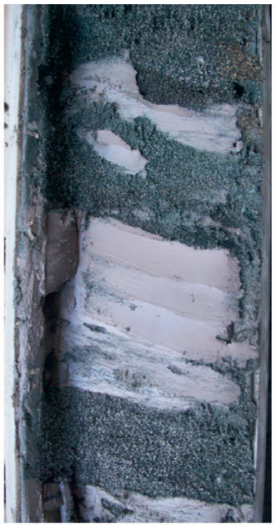

ON-Dessel-2

34.50-34.75m

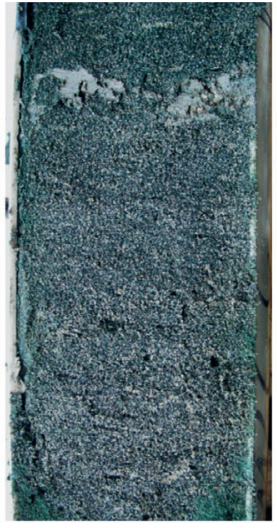

ON-Dessel-2

35.20-35.45m

$\begin{array}{cccc}\text { 'lower Mol' } & \begin{array}{c}\text { Reworked } \\ \text { Kasterlee }\end{array} & \begin{array}{c}\text { 'clayey } \\ \text { Kasterlee' }\end{array} & \begin{array}{c}\text { Reworked } \\ \text { Diest }\end{array}\end{array}$

'Iower Mol'

Kasterlee

Diest

'Coarse main body'

Diest Fm

Figure 8. Photographs of the ON-Dessel-2 borehole showing the lithological evolution of the sediment in the $25.00 \mathrm{~m}-35.45 \mathrm{~m}$ interval. The photographs show each identified unit, also the basal reworked sand units. In the photograph showing the 34.50-34.75 m depth interval, the boundary Diest-Kasterlee is present between $34.25 \mathrm{~m}$ and $34.65 \mathrm{~m}$.

This basal reworking is crucial to understand the stratigraphic complexity of these Formations and also to interpret boundaries in other boreholes or sections.

\subsubsection{The ON-Dessel-3 borehole}

Similar to the ON-Dessel-2 borehole, the stratigraphic boundaries of the ON-Dessel-3 borehole (DOV ON-Dessel-3 BGD 031W0354) are mainly based on characteristic gammaray jumps, grain size and correlation of the horizons identified in the ON-Dessel-2 borehole. As discussed in Vandenberghe et al. (2020, this volume), the base of the 'lower Mol' unit is placed at the erosive contact at $26.8 \mathrm{~m}$ with the presence of reworked sand between $26.8 \mathrm{~m}$ and $25.6 \mathrm{~m}$. The Diest-Kasterlee boundary is positioned at $35.2 \mathrm{~m}$ with a basal reworked sediment interval until approximately $33 \mathrm{~m}$ (see also photographs in Fig. 9).

The sediment analyses show that the clay mineralogy of the clayey top facies of the Diest Formation, is characterized by $>50 \%$ expandable clays, i.e. smectite and Fe-rich vermiculite (Fig. 10). The sediment in this lower section also has a poorly sorted grainsize distribution. Pelletal glauconite contents are higher than $40 \%$ and also the minerals siderite and chlorite and plagioclase are systematically detected in the $<32 \mu \mathrm{m}$ fraction. A sharp break in clay mineralogy is observed between $35.17 \mathrm{~m}$ and $34.67 \mathrm{~m}$, with a sudden decrease in expandable clay minerals in favor of kaolinite, illite and interstratified illite/smectite and glauconite/ smectite. This is interpreted as the boundary between the Diest Formation and the 'clayey Kasterlee' unit. Between $34.67 \mathrm{~m}$ and $33 \mathrm{~m}$, additional changes can be observed: 1) pelletal glauconite contents drop from $53 \%$ at the $34.27 \mathrm{~m}$ level to less than $20 \%$ at ca. $33 \mathrm{~m}, 2)$ the amounts of chlorite, siderite and plagioclase gradually disappear, 3) muscovite becomes more abundant and 4) grains with a size larger than $250 \mu \mathrm{m}$ significantly decrease. This interval is interpreted as the basal reworked sediment interval of the 'clayey Kasterlee' unit. From $33 \mathrm{~m}$ to $26.80 \mathrm{~m}$, the clay mineralogy hardly contains any expandable clays, the pelletal glauconite content is typically $5-7 \%$, chlorite, siderite and plagioclase are absent and grains $>250 \mu \mathrm{m}$ become scarce in the sediment. This $33 \mathrm{~m}-26.80 \mathrm{~m}$ interval is the 'clayey Kasterlee' unit. Between $28.5 \mathrm{~m}$ and $26.80 \mathrm{~m}$, the clay mineralogy shows an increase in interstratified glauconite/smectite (or clay-sized glauconite) and also the Fe content of the clay-sized glauconite decreases. The $26.8 \mathrm{~m}$ depth is interpreted as the base of the 'lower Mol' unit. Between $26.8 \mathrm{~m}$ and $25.6 \mathrm{~m}$, there is a significant change in clay mineralogy with increasing kaolinite contents.
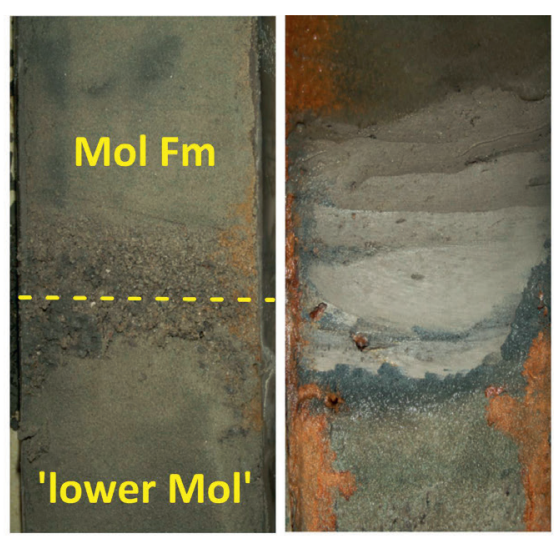

ON-Dessel-3 $13.00-13.25 m$ Detail $26.8 \mathrm{~m}$

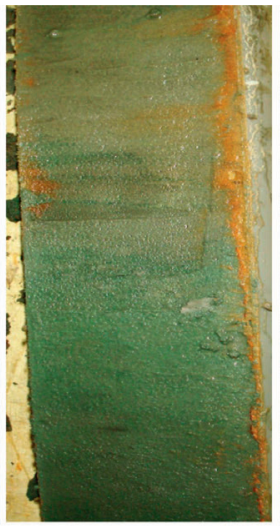

ON-Dessel-3 ON-Dessel-3
$27.70-27.95 m$

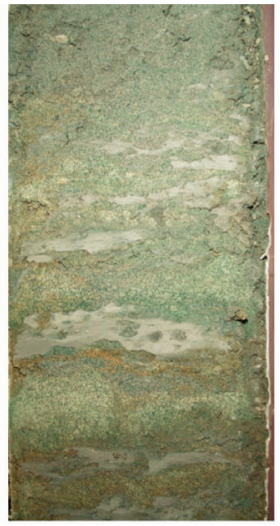

ON-Dessel-3

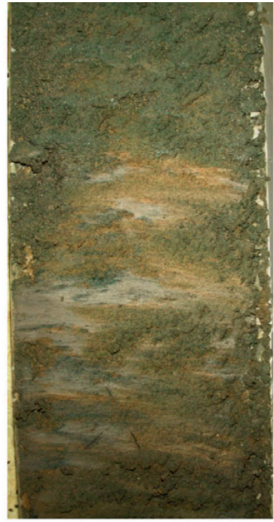

ON-Dessel-3 33.65-33.95m

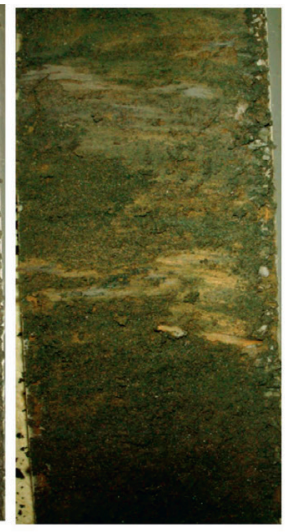

ON-Dessel-3

$$
\text { Top }
$$

'clayey Kasterlee'

\subsection{5-30.75m}

34.17-34.42m

$\begin{array}{cc}\text { Boundary } & \text { Erosive contact } \\ \text { Mol Fm \& } & \text { Reworked } \\ \text { 'lower Mol' } & \text { Kasterlee }\end{array}$

'clayey Kasterlee'

Reworked Diest

Reworked Diest

Figure 9. Photographs of the ON-Dessel-3 borehole showing the lithological evolution of the sediment in the $13.00 \mathrm{~m}-34.42 \mathrm{~m}$ interval. The photographs show each identified unit, also the basal reworked sand units, except the Diest Formation. 


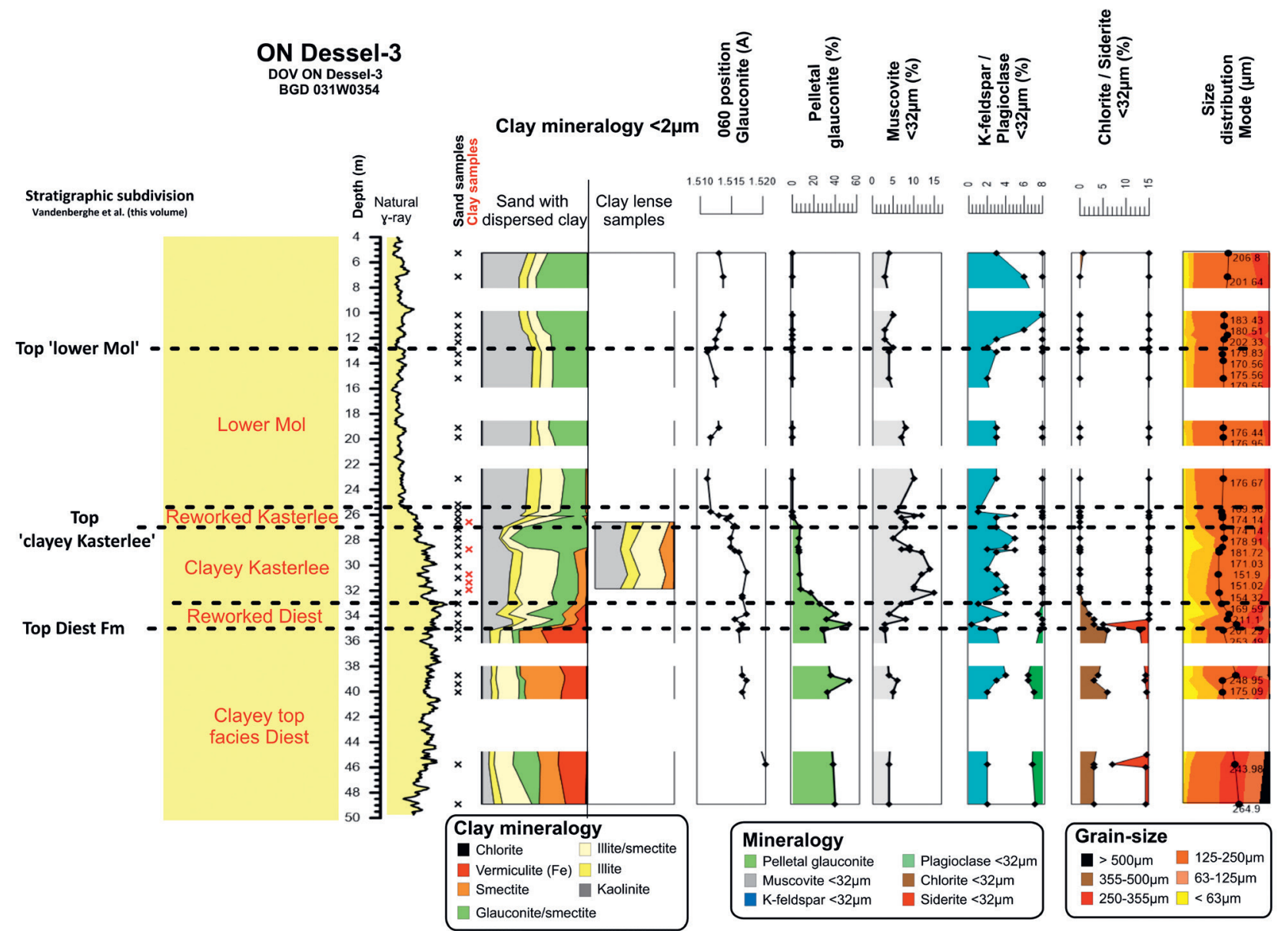

Figure 10. Overview of the clay mineralogy, pelletal glauconite content, mineralogical parameters and grain-size classes of the Dessel- 3 borehole. The stratigraphic subdivision is based on Vandenberghe et al. (2020, this volume). Both sand samples (black crosses) as clay lense samples (red crosses) were examined. The clay mineralogy shows an evolution of smectite and Fe-vermiculite in the clayey top facies of the Diest Formation towards more kaolinite and illite in the 'Clayey Kasterlee' unit and even more in the 'Lower Mol' unit.

Figure 11. Overview of the clay mineralogy, pelletal glauconite content, mineralogical parameters and grain-size classes of the Olen sluice outcrop. The stratigraphic subdivision is based on the position of the gravel layer reported by Louwye et al. (2007).

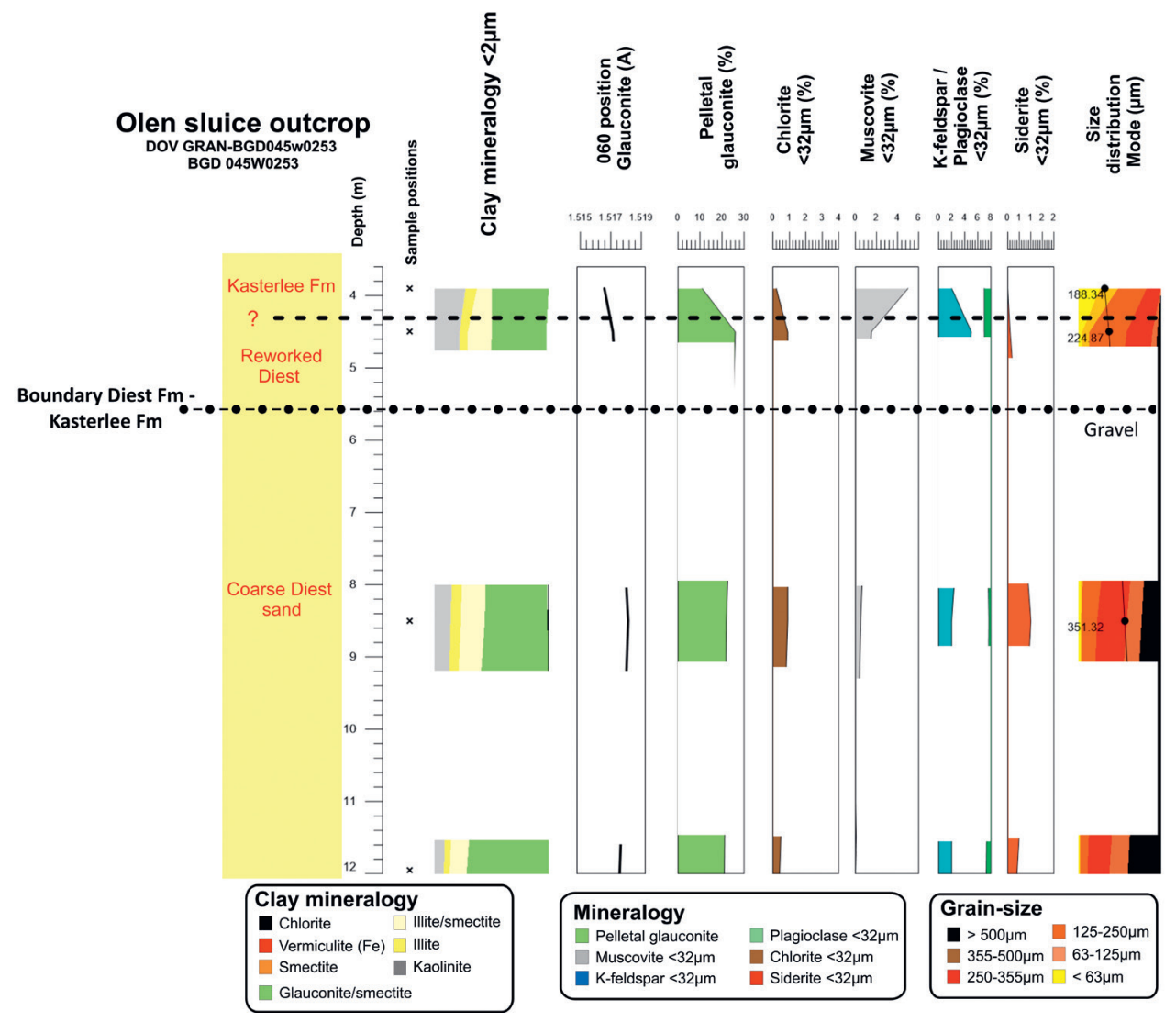




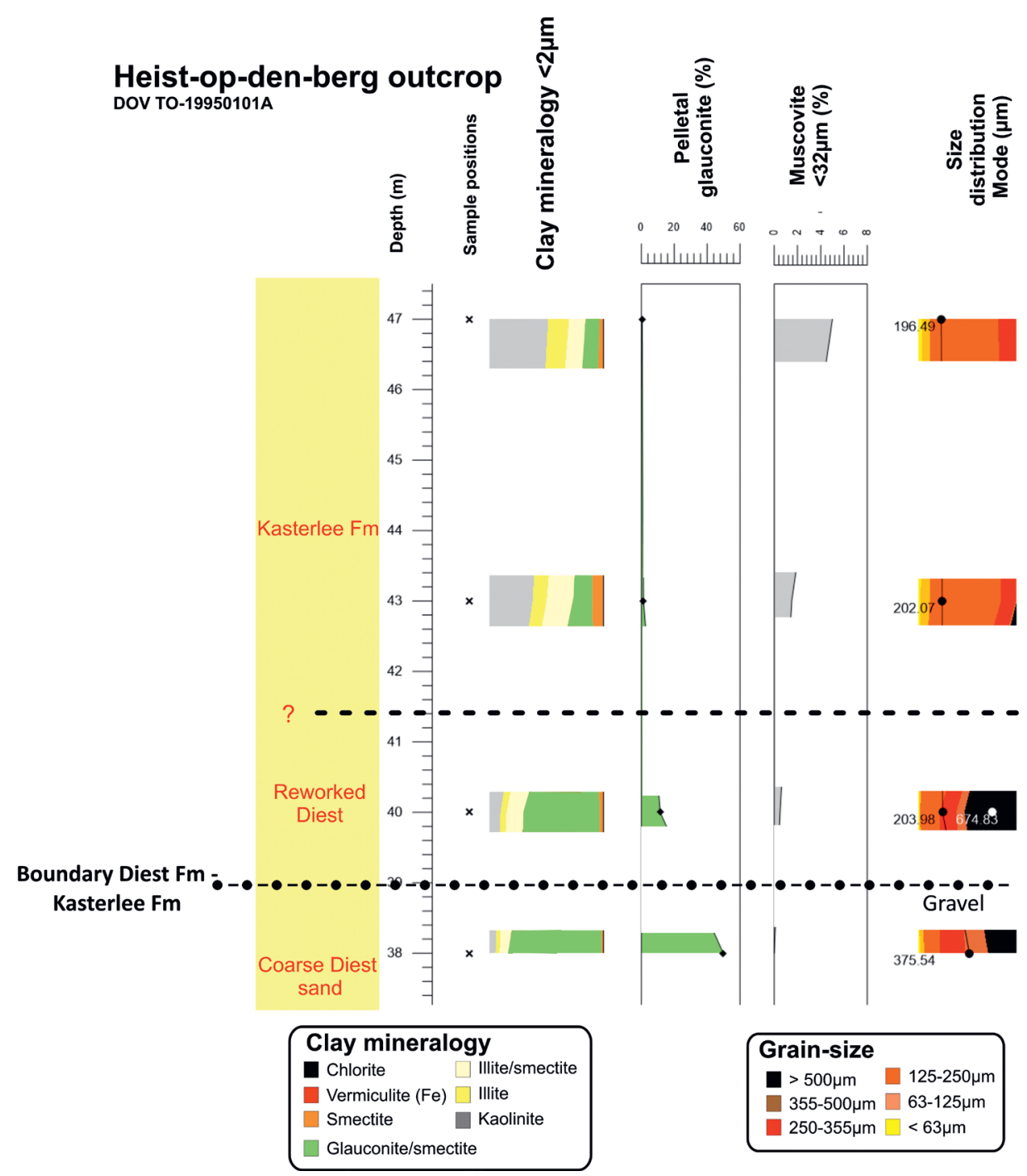

Figure 12. Overview of the clay mineralogy, pelletal glauconite content, mineralogical parameters and grain-size classes of the Heist-op-den-berg outcrop. The stratigraphic subdivision is based on the position of the gravel layer reported by Verhaegen et al. (2014).

Simultaneously, pelletal glauconite drops below $0.5 \%$ and the $\mathrm{Fe}$ content of clay-sized glauconite decreases drastically. This $26.8 \mathrm{~m}-25.6 \mathrm{~m}$ interval is the basal reworking unit of the "lower Mol' unit. The 'lower Mol' unit characterized by a kaolinite-rich clay mineralogy and uniform size distribution is present until $13.6 \mathrm{~m}$, above which the grain size seems to coarsen slightly and also the amount of $\mathrm{K}$-feldspar increases.

\subsection{The Diest-Kasterlee boundary in the Olen sluice and Heist- op-den-Berg outcrops}

The Diest-Kasterlee boundary was defined based on the presence of a gravel layer covering the Diest Formation in the Olen sluice outcrop (DOV GRAN-BGD045w0253_BGD 045W0253; Louwye et al., 2007). This gravel layer was later also reported at the Heist-op-den-Berg and Beerzel berg outcrops (Fobe, 1995; Verhaegen et al., 2014). In the Campine subsurface however, such a gravel layer is absent.

The Diest Formation in the Olen outcrop (Fig. 11) is characterized by a very coarse, clay poor sediment with pelletal glauconite contents of ca. $20 \%$, corresponding to the typical coarse Diest sand. The clay mineralogy consists mainly of interstratified glauconite/smectite and also illite, interstratified illite/smectite and kaolinite occur in minor amounts. Chlorite, siderite and plagioclase are detected in the $<32 \mu \mathrm{m}$ fraction of the samples. The analyzed samples of the Kasterlee Formation are positioned in the $2 \mathrm{~m}$ above gravel. The lowermost Kasterlee sample is only slightly less coarser-grained compared to the underlying Diest Formation samples and the mineralogy, clay mineralogy and pelletal glauconite content are rather similar. The uppermost Kasterlee sample however has a much finer grain size, contains only $10 \%$ pelletal glauconite and contains less chlorite and siderite. In both Kasterlee samples, an increase in muscovite and kaolinite is observed and the glauconitic Fe content is clearly lower compared to the Diest samples below suggesting a loss of structural Fe due to slightly more oxidative conditions during the Kasterlee deposition or alteration during reworking of the pellets.

A similar observation is made in the Heist-op-den-Berg outcrop (DOV TO-19950101A), where above the gravel layer covering the coarse Diest sand, $8 \mathrm{~m}$ of Kasterlee sediment is exposed (Verhaegen et al., 2020, this volume). The Diest sample is again coarse-sized with a low clay content and a high pelletal glauconite content $(49.8 \%)$ and the clay mineralogy consists mainly of interstratified glauconite/smectite (Fig. 12). The three samples above the gravel layer show different characteristics. The lowermost sample is still very coarse, has a pelletal glauconite content of $11.5 \%$ and the clay mineralogy contains slightly more kaolinite and illitic clay minerals compared to the Diest Formation sample below. The two uppermost samples however, are clearly more fine-grained, with much lower pelletal glauconite contents $(1.3 \%$ and $0.6 \%)$ and clearly higher muscovite contents. Furthermore, kaolinite has become the dominant clay mineral, even slightly more than in the 'clayey Kasterlee' facies of the ON-Dessel-2 and ON-Dessel-3 boreholes (see also Vandenberghe et al., 2020, this volume).

These results suggest a basal reworked sediment interval at the base of the Kasterlee Formation. This is analogous to the reworked sediment interpreted in the ON-boreholes. The difference with the ON-boreholes is that the top of the Diest Formation in the Olen and Heist-op-den-Berg outcrops is composed of the coarse Diest sand facies and not of the clayey top facies observed in the Campine subsurface. 


\section{Discussion: the contribution of clay mineralogy to the stratigraphy of the Diest-Kasterlee-Mol Formations and their boundaries}

The results of bulk mineralogy, clay mineralogy, pelletal glauconite content and grain-size distribution of sections of the Diest Formation show significant variability in sediment analysis parameters, allowing additional and improved characterization of the Diest Formation, the 'clayey Kasterlee' unit and the 'lower Mol' or 'Kasterlee-sensu-Gulinck' unit. Particular attention is paid to the boundaries between the different units.

\subsection{The Deurne Member}

The occurrence of the Deurne Member is restricted to the Antwerp area and is defined as a fine-grained glauconitic and calcareous sand unit at the base of the Diest Formation (see Houthuys et al., 2020, this volume and Goolaerts et al., 2020, this volume). In this work, only three samples of the Deurne Member were studied. The clay mineralogy of the Deurne samples is relatively smectiterich and this assemblage is very similar to the clay mineralogy of the Berchem Formation below.

\subsection{The Dessel Member}

The Dessel Member is a fine-grained glauconitic sand unit and only occurs in the subsurface of the Campine at the base of the Diest Formation. The relatively fine grain size is the decisive criterion to interpret the presence of the Dessel Member; in its lower part the Member is calcareous (see Houthuys et al., 2020, this volume).

It is proposed to assign overlying sediments to the Diest sand member when they become medium- to coarse-sized with a modal grain size exceeding $300 \mu \mathrm{m}$.

The clay mineralogy of the Dessel Member is similar to that of the underlying Berchem Formation with relatively high amounts of marine-derived smectite clay minerals and a very low kaolinite content, although interstratified glauconite/smectite is slightly more abundant in the Dessel Member sediment compared to the Berchem Formation. This unchanged clay mineralogy indicates that either the sediment provenance remained largely constant during the Miocene or that in addition Dessel Member sediment is massively reworked from earlier Miocene sediments which has also been suggested by Vandenberghe et al. (2014) based on the $\mathrm{K}$-Ar dates of pelletal glauconite.

\subsection{The coarse Diest sand facies in the Campine and the Hageland area}

Compared to the Dessel and Deurne Members, the coarse Diest sand in the Campine subsurface and in the Hageland is generally much coarser sized, poorly-sorted and typically showing an extremely low dispersed clay content. Characteristic for this loose sand is the coarse grain size with significant amounts of particles $>500 \mu \mathrm{m}$ with distribution modes typically in the $300-400 \mu \mathrm{m}$ interval. Pelletal glauconite contents are on average $40 \%$ with a range of $20 \%$ to $60 \%$. The clay mineralogy of the $<2 \mu \mathrm{m}$ fraction of sand samples is very different from the Dessel and Deurne Members and mainly consists of clay-sized glauconite with small amounts of smectite and very low kaolinite contents. In contrast, the clay mineralogy of the rarely occurring clay lenses is composed of mainly smectite and interstratified illite/smectite without any clay-sized glauconite and thus is similar to the clay mineralogy of the Deurne and Dessel Members. This clay mineralogical difference is a good illustration showing that clay-sized glauconite does not occur when pelletal glauconite is absent in the local environment and that the detrital clay content in the Diest Formation is composed of mainly smectite and interstratified illite/smectite. However as the detrital clay content is extremely low in the coarser Diest sand, and mainly derived from the abrasion of the abundant glauconite pellets in it, the marine detrital smectite and interstratified illite/smectite can hardly be detected in the coarse Diest sand itself. The occurrence of clay-sized glauconite depends on the energy in the depositional environment but it is foremost the detrital clay quantity in the sediment which determines how prominent clay-sized glauconite is. Based on (clay) mineralogy and size distribution, no distinction can be made between this coarse Diest sand facies in the Campine and the occurrence of the Diest Formation in the Hageland outcrops.

\subsection{The clayey top of the Diest Formation in the Campine}

The coarse Diest unit is covered by a more clayey glauconitic unit which forms the top of the Diest Formation in the Campine. The size distribution of this top part is typically very poorly sorted with an elevated clay content with distribution modes ranging between $170-250 \mu \mathrm{m}$. Pelletal glauconite contents of this unit are relatively high $(33 \%)$ but on average slightly lower compared to the coarser Diest unit below (38\%). The mineralogy is characterized by relatively high amounts of chlorite, plagioclase and secondaryformed siderite. The most typical for this clayey top part is the drastic change in clay mineralogy compared to the coarse Diest unit. The clay mineralogy consists of different types of swelling clay minerals, not only smectite (dioctahedral) but also relatively high proportions of Fe-rich vermiculite (trioctahedral). Whereas smectite is a very commonly reported clay mineral, vermiculite occurs much less frequent in sediments and is typically associated with (paleo)soil environments (Chamley, 1989). There are however no indications that this Diest sand sediment emerged to allow the in situ development of a soil. Therefore the vermiculite is more probably derived from the breakdown of glauconitic soils in the hinterland during the Late Tortonian to Early Messinian. The Fe-rich nature of this vermiculite strongly suggests a relation with the weathering of glauconite minerals, although the Ferich vermiculite is trioctahedral and not dioctahedral such as the interstratified glauconite/smectite minerals found in these sediments. The vermiculite is neither found in clay lenses in the clayey top Diest facies, which also suggests its origin is not simply detrital but should be related to glauconitic sand weathering the exact nature of which is not yet fully understood.

\subsection{The boundary between the Diest and Kasterlee Formations in the Campine}

The sediment analyses of both outcrop and Campine subsurface samples indicate the systematic presence of a reworked sediment interval approximately in the first two meters above the DiestKasterlee boundary. The petrological characteristics of the sediment in the outcrops and in the Campine subsurface are however different.

In the Campine subsurface, the clayey top facies of the Diest Formation is identified consisting of a poorly-sorted size distribution, a clay mineralogy with ca. 50\% swelling clays (smectite and Fe-rich vermiculite), a pelletal glauconite content of ca. 35\% and an increased chlorite and siderite content. Most characteristic is the presence of the Fe-rich vermiculite. The extent of this clayey top facies in the region has not been fully mapped but was identified in several boreholes in and around the towns of Dessel, Mol and possibly also extends to the east in the Limburg area although this needs further confirmation.

Above the reworked sediment, the 'clayey Kasterlee' unit sediment is characterized by a medium- to well-sorted size distribution, a clay mineralogy with low amounts of swelling clay minerals and clearly higher kaolinite and clay-sized glauconite contents, pelletal glauconite contents no higher than $6 \%$ and elevated muscovite flake contents around $10 \%$. In the Olen sluice and Heist-op-den-Berg outcrops, the clay top facies of the Diest Formation is absent and the coarse Diest sand, with a typical coarse size distribution, high pelletal glauconite contents and a clay mineralogy consisting of mainly clay-sized glauconite, forms the top of the Formation. These characteristics are naturally also found in the interval with reworked sediment above and differ from the characteristics (e.g. the presence of Fe-rich vermiculite) of the reworked sediment interval in the ON-Dessel-2 and ONDessel-3 boreholes where the Diest Formation is composed of the clayey top facies.

The change in clay mineralogy with systematically higher kaolinite contents in the 'clayey Kasterlee' compared to the Diest Formation below coincides with the increased continental influence at this transition reported by Louwye et al. (2007).

The gravel observed in the outcrops indicates an important paleogeographic change between the Diest and Kasterlee Formations. In the Campine subsurface, gravel is not detected at the boundary but the Fe-rich vermiculite characteristic for the clayey top facies of the Diest Formation is absent in the "clayey Kasterlee' unit. This indicates the end of detrital glauconitic soil input and therefore also marks a relevant paleogeographic change. 


\subsection{The 'clayey Kasterlee'-'lower Mol' boundary in the Campine}

The top of the 'clayey Kasterlee' unit in the Campine subsurface is identified by a marked GR jump (see Vandenberghe et al., 2020, this volume). Above this level, the 'lower Mol' unit is identified of which the top is defined when the sediment picks up a significant amount of $>250 \mu \mathrm{m}$ size fraction. This coarser sand above the 'lower Mol' unit is the classical Mol Sand Formation mapped in the area. Verhaegen (2020, this volume) concluded that the heavy minerals of the 'Lower Mol' unit are similar to the Mol Formation heavy minerals and are much less related to the 'clayey Kasterlee' heavy minerals.

The sediment analyses performed in this work indicate, analogous to the base of the Kasterlee Formation, the presence of an approximately 2 m-thick reworked sediment interval at the base of the 'lower Mol' unit. The most significant changes in sediment characteristics occur at the top of this basal interval (approximately $26 \mathrm{~m}$ in ON-Dessel-2 and $26.8 \mathrm{~m}$ in the ONDessel-3 borehole, see Vandenberghe et al., 2020, this volume) by a clear increase of kaolinite content, a decrease of the muscovite content and clay-sized glauconite as well as a dramatic decrease in the glauconitic Fe-content type $\left(d_{060}\right)$ of glauconite minerals incorporated in sand- and clay-sized fractions (see Fig. 7 and Fig. 10). The end of the reworking is also announced by palynological changes as the paleoenvironment becomes much more continental upwards from this depth level (Louwye et al., 2007).

The simultaneous and sharp increase in kaolinite and decrease in glauconitic Fe marks a notable event, namely that the sediment is now dominantly derived from the continent.

The occurrence of clay-sized glauconite in the 'lower Mol' unit, which can be easily observed by the olive-green color of the separated clay fraction, is considered as reworking, as pelletal glauconite is absent in this unit. Furthermore, the clay-sized glauconite contains much less structural $\mathrm{Fe}$ in the 'lower Mol' unit compared to the 'clayey Kasterlee' unit. This slightly lower $\mathrm{Fe}$ content is explained by the loss of Fe during reworking and transport in a progressively more oxidative environment. Several authors have reported occurrences of Fe-poor glauconite in continental or estuarine conditions (Berg-Madsen, 1983; Weaver \& Pollard, 1973; Meunier, 2005). However, in these cases the Fe content of the glauconitic minerals is much lower compared to the Belgian glauconitic minerals and an important diagenetic imprint is suspected. Although the exact process is not yet fully understood, the loss of structural Fe is most logically related to the systematic and continuous reworking of pelletal and claysized glauconite in these sediments.

\section{Conclusions}

The mineralogical characterization of the different Neogene deposits revealed significant variation in clay mineralogical composition. This variation in clay mineralogy is linked to changes in the sedimentary environment. Detrital clay material of the Berchem and Diest Formations has a dominantly marine origin consisting of mainly smectite and interstratified illite/ smectite and little or no kaolinite and illite. Whenever the detrital clay content is low, for instance in the coarse Diest sand in the Campine and in the Hageland, clay-sized glauconite is the most abundant clay mineral as the local degradation of pelletal glauconite becomes the main clay-forming mechanism.

The evolution of the Diest Formation to the Kasterlee and Mol Formations is characterized by the disappearance of smectitic clay minerals whereas kaolinite and illite become gradually more important. This increase in kaolinite and illite clay minerals is a response to the increasing continental influence in the Campine basin during the end of the Miocene and start of the Pliocene. The presence of Fe-rich vermiculite in the top of the Diest Formation indicates the influx of glauconitic soil material which up to present remained unnoticed. Pelletal and clay-sized glauconite are constantly reworked in these sediments leading to a loss in structural iron.

It has been demonstrated that the clay mineralogy responds to important sedimentary changes and therefore is useful for lithostratigraphic correlation, to define stratigraphic boundaries and better understand gamma-ray signals. The systematic clay mineralogical characterization furthermore has allowed to identify basal reworked sediment at the base of the Kasterlee Formation and 'lower Mol' unit. The identification of these reworked sediment intervals is crucial to understand the Diest-Kasterlee and Kasterlee-Mol boundaries and identify the boundaries at other stratigraphic sections and locations.

Although the sampling density of this reconnaissance study should be increased in the crucial depth intervals to define more precise boundaries, the results of this study already allow a better understanding of the Diest-Kasterlee-Mol stratigraphic issue and gives insights in the sediment origin. The results of this reconnaissance study should be further explored laterally in the Campine basin

\section{Acknowledgements}

ONDRAF-NIRAS is thanked for authorization to sample the boreholes from the Dessel-Mol area and SCK-Euridice for providing practical help with the sampling of these boreholes. The Geological Survey of Belgium, and in particular Marleen De Ceukelaire, is thanked for the authorization and help in sampling the Rijkevorsel 016E153 borehole. PIDPA is thanked for their authorization to sample the Mol 31E0435 borehole.

Chevron ETC, Houston is thanked for permission to use the proprietary software Quanta, Sybilla.

The reviewers Eric Van Ranst and Abder El Albani are thanked for their constructive and detailed comments that helped to improve our original manuscript.

\section{References}

Adriaens, R., 2015. Neogene and Quaternary clay minerals in the southern North Sea. Unpublished Ph.D. Thesis, KU Leuven, Leuven, 272 p. https://limo.libis.be/primo-explore/fulldisplay?docid=LIRIAS193 $0587 \&$ context $=$ L\&vid $=$ Lirias\&search_scope $=$ Lirias\&tab $=$ default tab\&lang=en_US\&fromSitemap=1, accessed 18/06/2020.

Adriaens, R., Vandenberghe, N. \& Elsen, J., 2014. Natural clay-sized glauconite in the Neogene deposits of the Campine basin (Belgium). Clays and Clay Minerals, 62, 35-52. https://doi.org/10.1346/ ccmn.2014.0620104

Berg-Madsen, V., 1983. High-alumina glaucony from the Middle Cambrian of Öland and Bornholm, Southern Baltoscandia. Journal of Sedimentary Petrology, 53/3, 875-893. https://doi. org/10.1306/212F82DD-2B24-11D7-8648000102C1865D

Chamley, H., 1989. Clay Sedimentology. Springer, Berlin, 623 p. https:// doi.org/10.1007/978-3-642-85916-8

Databank Ondergrond Vlaanderen, 2020. Tertiair geologische kaart (1/50.000). https://www.dov.vlaanderen.be/geonetwork/ srv/dut/catalog.search\#/metadata/06d1a1d7-d46c-43d6-96aa25225b57dd8b, accessed 18/06/2020.

De Meuter, F. \& Laga, P., 1976. Lithostratigraphy and biostratigraphy based on benthonic foraminifera of the Neogene deposits in Northern Belgium. Bulletin van de Belgische Vereniging voor Geologie/ Bulletin de la Société belge de Géologie, 85/3-4, 133-152.

Fobe, B., 1995. Lithologie en lithostratigrafie van de Formatie van Kasterlee (Plioceen van de Kempen), Natuurwetenschappelijk Tijdschrift, 75/2, 35-45.

Goolaerts, S., Hoedemaekers, K., Van Herck, M., Adriaens, R., Bosselaers, M., Bruneel, Y., De Ceuster, J., Elsen, E., Gijsen, B., Houthuys, R., Mollen, F., Lambert, O., Uchman, A. \& Louwye, S., 2020. The Deurne Member of the Diest Formation revisited: unexpected revelations from studying a large temporary outcrop near Antwerpen international airport exposing middle to upper Miocene sediments. Geologica Belgica, 23/3-4, this volume. https://doi.org/10.20341/ gb.2020.011

Gulinck, M., 1963. Essai d'une Carte géologique de la Campine. Etat de nos connaissances sur la nature des terrains néogènes recoupés par sondages. In Symposium sur la stratigraphie du Néogène nordique, Gand 1961. Société belge de Géologie, de Paléontologie et d'Hydrologie, Mémoires in- $8^{\circ}, 6,30-39$.

Gulinck, M. \& Laga, P., 1975. Lithological description and foraminifera investigation of the Oostmalle - Rijkevorsel 16e153 borehole. Unpublished notes of P. Laga. Archives of the Belgian Geological Survey, Brussels.

Hermanns K., 1992. Untersuchungen in neogenen Tonschichten des Rheinischen Braunkohlenreviers, südliche Niederrheinische Bucht. Bonner Geowissenschaftliche Schriften, 2, 203 p. 
Houthuys, R., Adriaens, R., Goolaerts, S., Laga, P., Louwye, S., Matthijs, J., Vandenberghe, N. \& Verhaegen, J., 2020. The Diest Formation: review of insights from the last decades. Geologica Belgica, 23/3-4, this volume. https://doi.org/10.20341/gb.2020.012

Jackson, M.L., 1975. Soil Chemical Analysis - Advanced course. $2^{\text {nd }}$ ed. Madison, Wisconsin, Published by the author, $895 \mathrm{p}$.

Labat, S., Gedeon, M., Beerten, K. \& Maes, T., 2011. Dessel-5 borehole: technical aspects and hydrogeological investigations. SCK $\cdot \mathrm{CEN}$, Mol, External report SCK•CEN-ER-151, 38 p.

Laga, P., Louwye, S. \& Geets, S., 2001. Paleogene and Neogene lithostratigraphic units (Belgium). In Bultynck, P. \& Dejonghe, L. (eds), Guide to a revised lithostratigraphic scale of Belgium. Geologica Belgica, 4/1-2, 135-152. https://doi.org/10.20341/ gb. 2014.050

Louwye, S., 2000. Dinoflagellate cysts and acritarchs from the Miocene Zonderschot sands, Northern Belgium: stratigraphic significance and correlation with contiguous areas. Geologica Belgica, 3/1-2, 55-65. https://doi.org/10.20341/gb.2014.023

Louwye, S., 2005. The Early and Middle Miocene transgression at the southern border of the North Sea Basin (northern Belgium). Geological Journal, 40, 441-456. http://dx.doi.org/10.1002/gj.1021

Louwye, S. \& De Schepper, S., 2010. The Miocene-Pliocene hiatus in the southern North Sea Basin (northern Belgium) revealed by dinoflagellate cysts. Geological Magazine, 5, 760-776. https://doi. org/10.1017/S0016756810000191

Louwye, S., De Coninck, J., \& Verniers, S., 1999. Dinoflagellate cyst stratigraphy and depositional history of Miocene and Lower Pliocene formations in northern Belgium (southern North Sea basin). Geologie en Mijnbouw, 78, 31-46. https://doi.org/10.1023/A:1003793300214

Louwye, S., De Schepper, S., Laga, P., \& Vandenberghe, N., 2007. The Upper Miocene of the southern North Sea Basin (northern Belgium): a palaeoenvironmental and stratigraphical reconstruction using dinoflagellate cysts. Geological Magazine, 144/1, 33-52. https://doi. org/10.1017/S0016756806002627

Louwye, S., Deckers, J., Verhaegen, J., Adriaens, R. \& Vandenberghe, N., 2020. A review of the lower and middle Miocene in northern Belgium. Geologica Belgica, 23/3-4, this volume. https://doi. org/10.20341/gb.2020.010

Meunier, A., 2005. Clays. Springer, Berlin, 472 p. https://doi.org/10.1007/ b138672

Meunier, A. \& El Albani, A., 2007. The glauconite-Fe-illite-Fe-smectite problem: a critical review. Terra Nova, 19, 95-104. https://doi. org/10.1111/j.1365-3121.2006.00719.x

Moore, D.M. \& Reynolds, R.C., Jr., 1997. X-Ray Diffraction and the Identification and Analysis of Clay Minerals. $2^{\text {nd }}$ ed. Oxford University Press, Oxford, $378 \mathrm{p}$.

Schiltz, M., 2020. On the use of CPTs in stratigraphy: recent observations and some illustrative cases. Geologica Belgica, 23/3-4, this volume. https://doi.org/10.20341/gb.2020.019

Van Ranst, E. \& De Coninck, F., 1983, Evolution of glauconite in imperfectly drained sandy soils of the Belgian Campine. Zeitschrift für Pflanzenernährung und Bodenkunde, 146, 415-426. https://doi. org/10.1002/jpln.19831460403

Vandenberghe, N. \& Louwye, S. (eds), 2020. The Neogene stratigraphy of northern Belgium. Geologica Belgica, 23/3-4, this volume. https:// doi.org/10.20341/gb.23.3-4

Vandenberghe, N., Harris, W.B., Wampler, J.M., Houthuys, R., Louwye, S., Adriaens, R., Vos, K., Lanckacker, T., Matthijs, J., Deckers, J., Verhaegen, J., Laga, P., Westerhoff, W. \& Munsterman, D., 2014. The implications of K-Ar glauconite dating of the Diest Formation on the paleogeography of the Upper Miocene in Belgium. Geologica Belgica, 17, 161-174.

Vandenberghe, N., Wouters, L., Schiltz, M., Beerten, K., Berwouts, I., Vos, K., Houthuys, R., Deckers, J., Louwye, S., Laga, P., Verhaegen, J., Adriaens, R. \& Dusar, M., 2020. The Kasterlee Formation and its relation with the Diest and Mol Formations in the Belgian Campine. Geologica Belgica, 23/3-4, this volume. https://doi.org/10.20341/ gb. 2020.014

Verhaegen, J., 2020. Stratigraphic discriminatory potential of heavy mineral analysis for the Neogene sediments of Belgium. Geologica Belgica, 23/3-4, this volume. https://doi.org/10.20341/gb.2020.003

Verhaegen, J., Adriaens, R., Louwye, S., Vandenberghe, N. \& Vos, K., 2014. Sediment-petrological study supporting the presence of the Kasterlee Formation in the Heist-op-den-Berg and Beerzel hills, southern Antwerp Campine, Belgium. Geologica Belgica, 17, 323-332.
Verhaegen, J., Frederickx, L. \& Schiltz, M., 2020. New insights into the lithostratigraphy and paleogeography of the Messinian Kasterlee Formation from the analysis of a temporary outcrop. Geologica Belgica, 23/3-4, this volume. https://doi.org/10.20341/gb.2020.015

Weaver, C.E. \& Pollard, L.D., 1973. The Chemistry of Clay Minerals. Elsevier, Amsterdam, Developments in Sedimentology, 15, 213 p.

Wouters, L. \& Schiltz, M., 2012. Overview of the field investigations in and around the nuclear site of Mol-Dessel. ONDRAF/NIRAS NIROND-TR report 2011-42 E, 100 p.
Manuscript received 22.04.2020, accepted in revised form 28.06.2020, available online 13.08.2020. 